SANDIA REPORT

SAND2001-2945

Unlimited Release

Printed September 2001

\title{
Compliance Assessment Document for the Transuranic Wastes in the Greater Confinement Disposal Boreholes at the Nevada Test Site
}

\section{Volume 4: Application of Assurance Requirements}

Version 2.0

Doug A. Brosseau

Prepared By Sandia National Laboratories

Albuquerque, New Mexico 87185 and Livermore, California 94550

Sandia is a multiprogram laboratory operated by Sandia Corporation, a Lockheed Martin Company, for the United States Department of Energy under contract DE-AC04-94AL85000.

Approved for public release; further dissemination unlimited.

(14.) Sandia National Laboratories

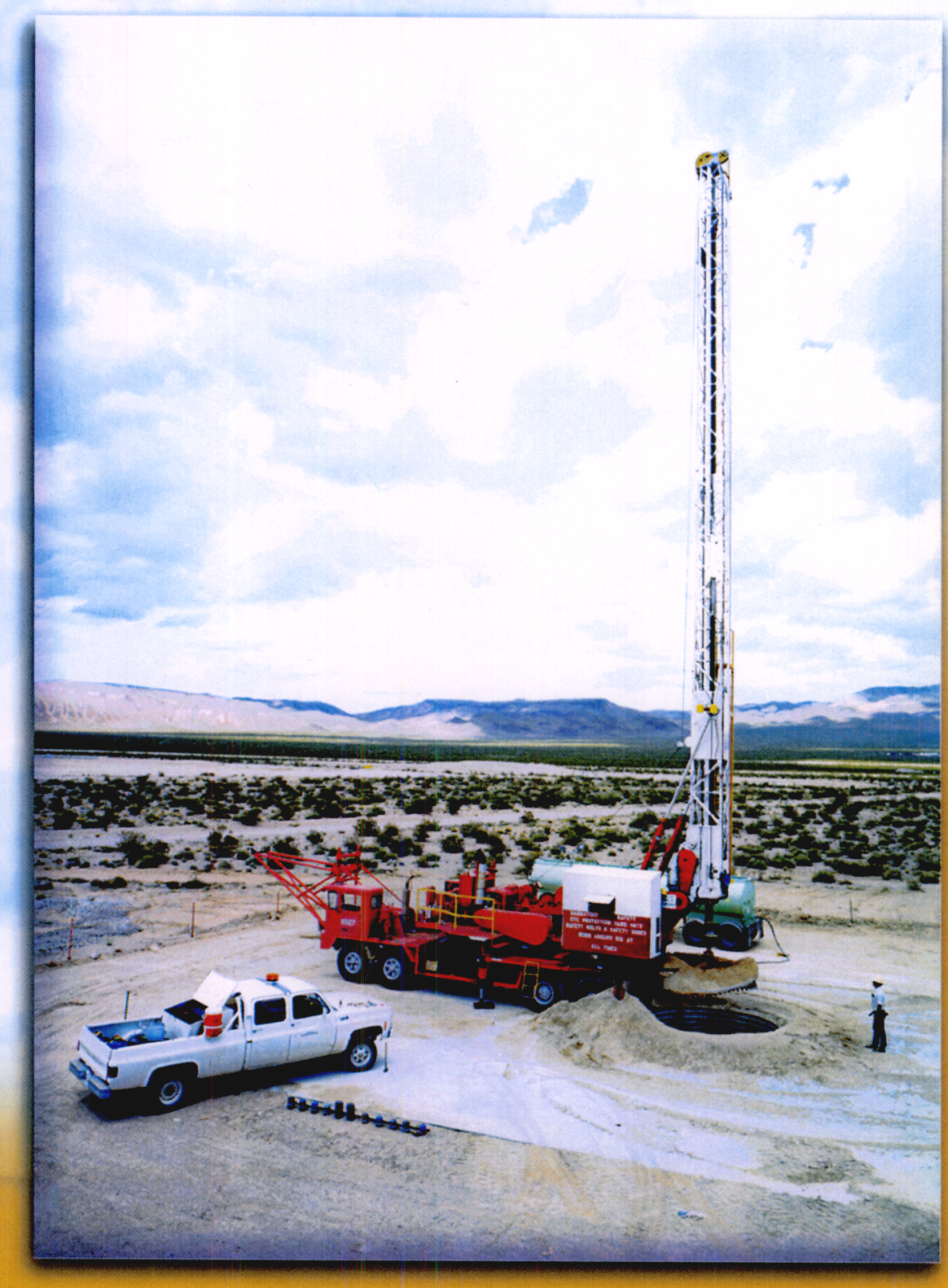


Issued by Sandia National Laboratories, operated for the United States Department of Energy by Sandia Corporation.

NOTICE: This report was prepared as an account of work sponsored by an agency of the United States Government. Neither the United States Government, nor any agency thereof, nor any of their employees, nor any of their contractors, subcontractors, or their employees, make any warranty, express or implied, or assume any legal liability or responsibility for the accuracy, completeness, or usefulness of any information, apparatus, product, or process disclosed, or represent that its use would not infringe privately owned rights. Reference herein to any specific commercial product, process, or service by trade name, trademark, manufacturer, or otherwise, does not necessarily constitute or imply its endorsement, recommendation, or favoring by the United States Government, any agency thereof, or any of their contractors or subcontractors. The views and opinions expressed herein do not necessarily state or reflect those of the United States Government, any agency thereof, or any of their contractors.

Printed in the United States of America. This report has been reproduced directly from the best available copy.

Available to DOE and DOE contractors from

U.S. Department of Energy

Office of Scientific and Technical Information

P.O. Box 62

Oak Ridge, TN 37831

Telephone: (865)576-8401

Facsimile: (865)576-5728

E-Mail: reports@adonis.osti.gov

Online ordering: http://www.doe.gov/bridge

Available to the public from

U.S. Department of Commerce

National Technical Information Service

5285 Port Royal Rd

Springfield, VA 22161

Telephone: (800)553-6847

Facsimile: (703)605-6900

E-Mail: orders@ntis.fedworld.gov

Online order: http://www.ntis.gov/ordering.htm

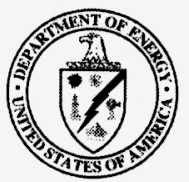


SAND2001-2945

Unlimited Release

Printed September 2001

\title{
Compliance Assessment Document for the Transuranic Wastes in the Greater Confinement Disposal Boreholes at the Nevada Test Site Volume 4: Application of Assurance Requirements
}

\author{
Doug A. Brosseau \\ Geohydrology Department \\ Sandia National Laboratories \\ P.O. Box 5800 \\ Albuquerque, NM 87185-0735
}

\begin{abstract}
This report describes how the U.S. Department of Energy, Nevada (DOE/NV) will comply with the qualitative Assurance Requirements specified in 40 CFR 191 that are applicable to disposal of transuranic (TRU) wastes in the Greater Confinement Disposal (GCD) boreholes located in the Area 5 Radioactive Waste Management Site in the Nevada Test Site (NTS). Volume 4 is a companion document to the GCD Compliance Assessment Document (CAD) that presents the performance assessment of TRU wastes in the GCD boreholes against the quantitative performance measures specified in 40 CFR 191.

This volume of the CAD briefly describes the site and disposal facility and summarizes current assurance provisions at the NTS and those associated with the Area 5 disposal facilities. It also complements the extensive discussion of the regulatory basis for GCD disposal at the NTS in Volume 2 of the $\mathrm{CAD}$ by summarizing the Assurance Requirements and their relationship to the quantitative requirements of $40 \mathrm{CFR}$ 191. An important conclusion of this report is that the performance assessment process used to demonstrate compliance represents and treats uncertainty throughout the process and, as such, minimizes the need for exhaustive reliance on the Assurance Requirements.

The analysis of the applicability of the Assurance Requirements to the GCD disposal concept and disposal facilities at the NTS was supported by subject matter expert (SME) views and opinions expressed during an expert elicitation conducted for NTS Areas 3 and 5. The SMEs recommended periodic review of assurance provisions and the performance assessment to address societal and technological advances that could change conditions and the relevant state of knowledge regarding system performance and the assurance needed for DOE to continue to demonstrate compliance. This report also recognizes the need for long-term financial assurance to support the assurance provisions.

Finally, this report summarizes specific actions DOE/NV will take prior to and following closure of the Area 5 disposal facilities, including the GCD boreholes, in order to meet the Assurance Requirements. Emphasis is placed on active institutional control provisions, planning and eventual implementation of passive institutional control provisions, and implementation of limited monitoring requirements integrated with the Area 5 and site-wide monitoring and closure programs.
\end{abstract}




\section{ACKNOWLEDGMENTS}

Throughout the development of this Volume 4 on Assurance Requirements for the Compliance Assessment for the Greater Confinement Disposal system, exceptional managerial and technical leadership was provided by Angela Colarusso, Wendy Clayton, and Beth Moore from the U.S. Department of Energy, Nevada Operations Office (DOE/NV). The author would also like to thank John Cochran and Paul Davis from Sandia National Laboratories, Albuquerque, New Mexico for their input and technical leadership. Significant input and advice on DOE plans for long-term stewardship and "paths to closure" were offered by Bobbie McClure, DOE/NV. Paul Black, John Tauxe, and Tom Stockton from Neptune \& Company, Los Alamos, New Mexico provided significant input, review and recommendations in the development of this report. A number of staff from Bechtel Nevada, particularly Stu Rawlinson, provided additional technical input and documents on Nevada Test Site closure plans. Finally, Laura Price, Beta Corporation, Phoenix, Arizona took time out to provide a thorough review of the entire document for technical adequacy and readability. The author thanks all those who participated in developing and finalizing this report.

\section{PREFACE}

Sandia National Laboratories has completed this Compliance Assessment Document (CAD) using all available information and an iterative performance assessment methodology. The Sandia National Laboratories team members provided the expertise in the broad suite of disciplines necessary to complete this CAD. The CAD, from its inception, has been peer reviewed by representatives of the U.S. Department of Energy (DOE), Nevada Operations Office (DOE/NV), and DOE/NV contractors, including representatives from Bechtel Nevada, Neptune and Company, Desert Research Institute, Harry Reid Center for Environmental Studies, and HSI GeoTrans. Sandia National Laboratories is comfortable defending the CAD as presented. However, this CAD is undergoing a DOE Headquarters (DOE/HQ) peer review. Many of the preliminary recommendations of the DOE/HQ Review Team have been incorporated in this Version 2.0. Appendix B to Volume 4 of the CAD summarizes responses to comments and issues received as this Volume was being published. Any subsequent final publication of the CAD will incorporate, as necessary, any additional changes responsive to the DOE/HQ peer review. 


\section{TABLE OF CONTENTS}

$\underline{\text { Page }}$

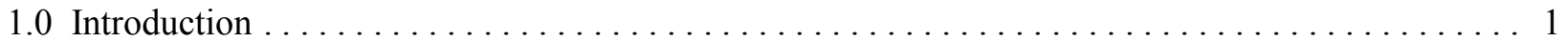

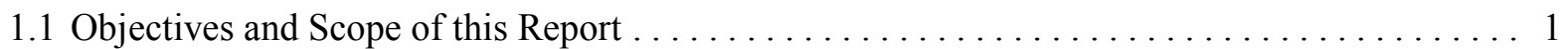

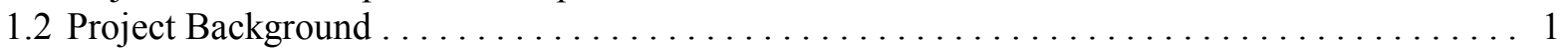

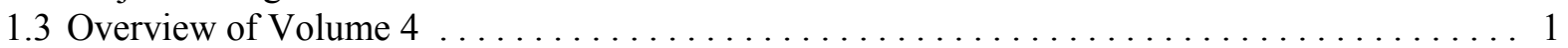

1.4 Overview of Regulatory Basis for Assurance Requirements $\ldots \ldots \ldots \ldots \ldots \ldots \ldots \ldots 2$

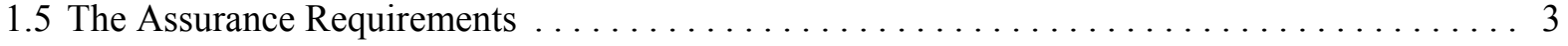

1.5.1 Siting to Avoid Mined or Accessible Resources . . . . . . . . . . . . . . . . . . 3

1.5.2 Design for Future Removal of Waste $\ldots \ldots \ldots \ldots \ldots \ldots \ldots \ldots \ldots \ldots \ldots$

1.5.3 Isolate Via Engineered and Natural Barriers . . . . . . . . . . . . . . . 4

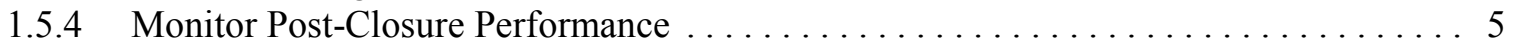

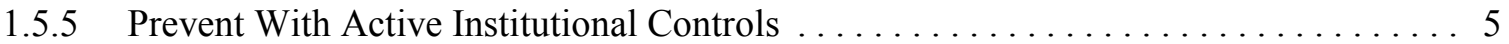

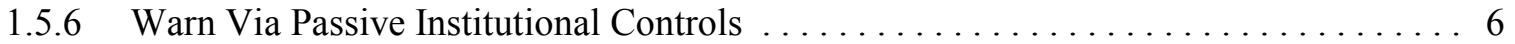

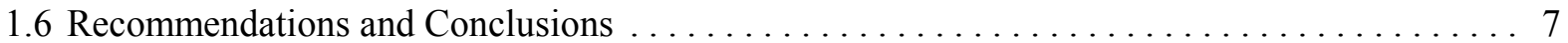

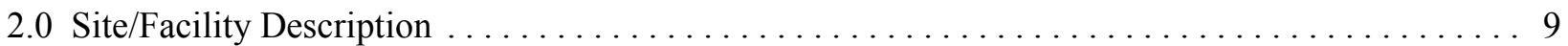

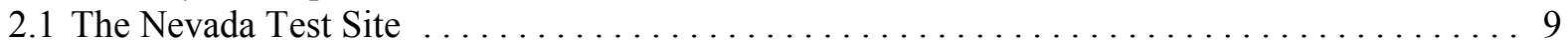

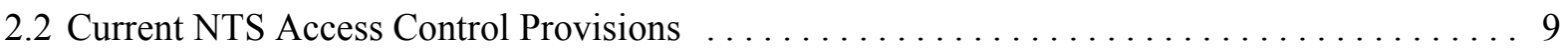

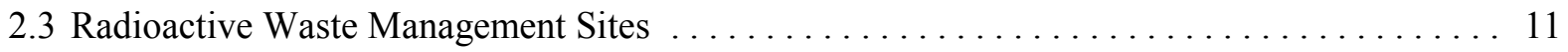

2.4 Greater Confinement Disposal Boreholes $\ldots \ldots \ldots \ldots \ldots \ldots \ldots \ldots \ldots \ldots \ldots \ldots \ldots . \ldots \ldots$

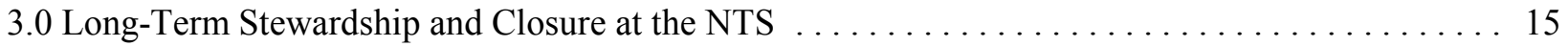

3.1 Closure Requirements for LLW in the Area 5 RWMS $\ldots \ldots \ldots \ldots \ldots \ldots \ldots \ldots \ldots$

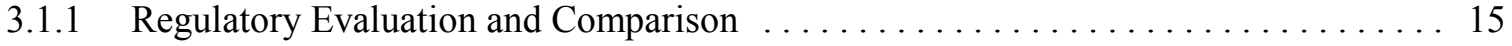

3.1.2 Closure Plan for the Area 5 RWMS LLW Disposal Units $\ldots \ldots \ldots \ldots \ldots \ldots \ldots . \ldots$

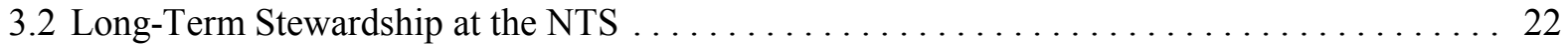

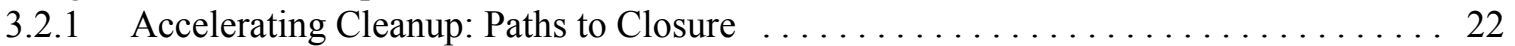

3.2.2 Accelerating Cleanup: Paths to Closure, Nevada Operations Office . . . . . . . . . . 22

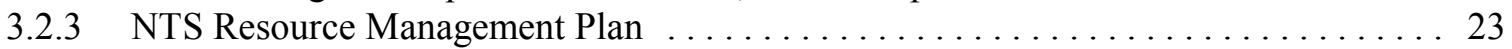

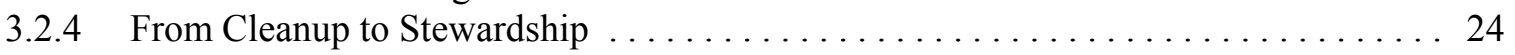

4.0 Application of Assurance Requirements at the GCD Site $\ldots \ldots \ldots \ldots \ldots \ldots \ldots \ldots \ldots \ldots$

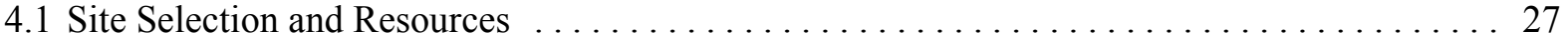

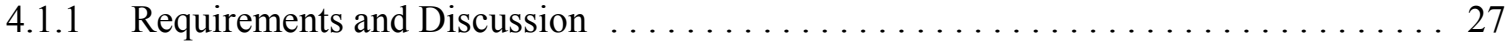

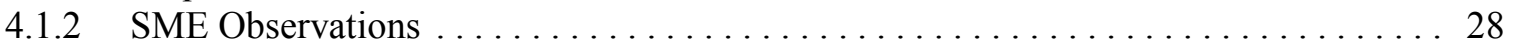

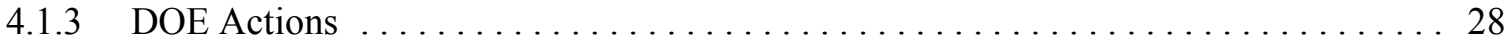

4.2 Future Waste Removal ..................................... 29

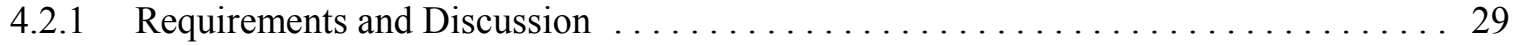

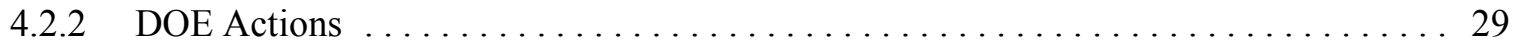

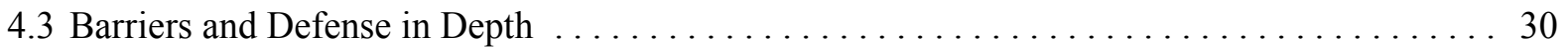

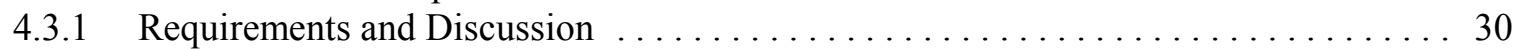

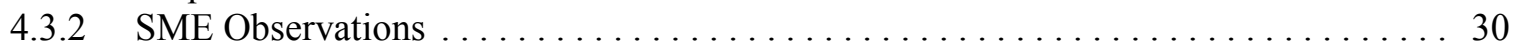

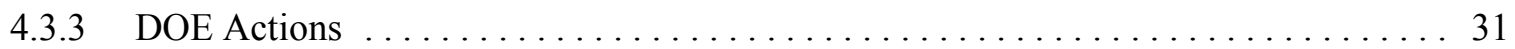

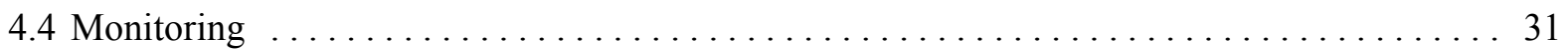




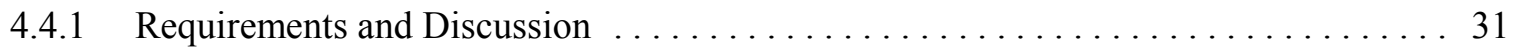

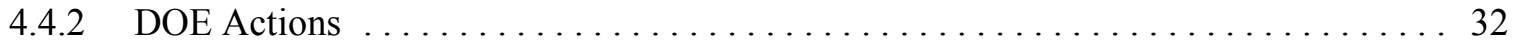

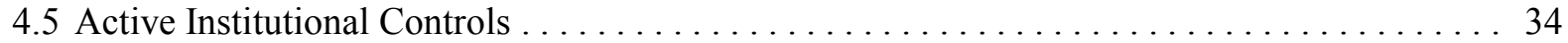

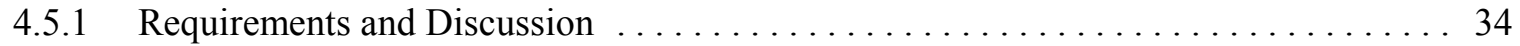

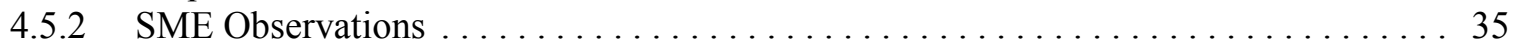

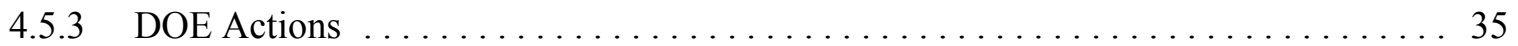

4.6 Passive Institutional Controls . . . . . . . . . . . . . . . . . . . . . . . . . . . . . . 39

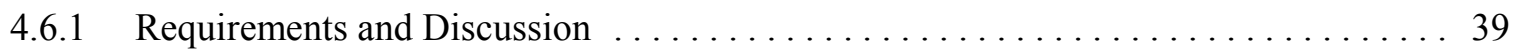

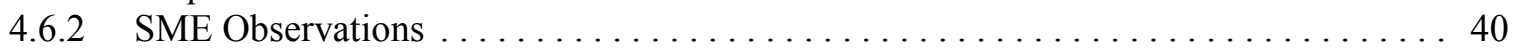

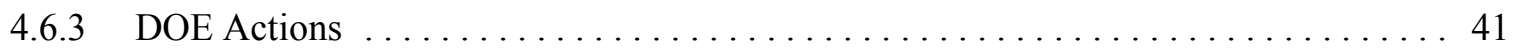

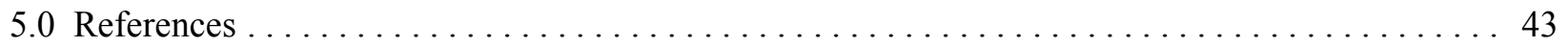

Appendix A - Assurance Provisions for the Waste Isolation Pilot Plant $\ldots \ldots \ldots \ldots \ldots \ldots \ldots$ A-1

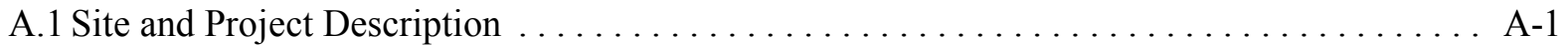

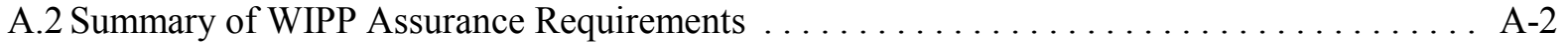

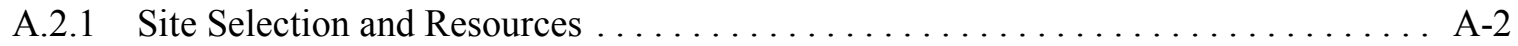

A.2.2 Future Waste Removal . . . . . . . . . . . . . . . . .

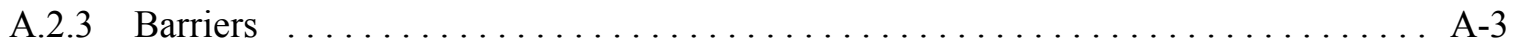

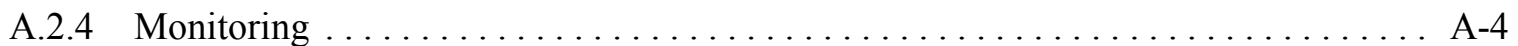

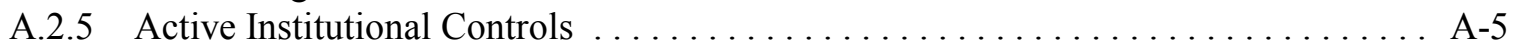

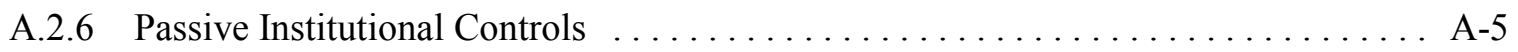

Appendix B - Response to DOE/HQ Review Team Issues $\ldots \ldots \ldots \ldots \ldots \ldots \ldots \ldots \ldots \ldots$ B-1 


\section{FIGURES}

$\underline{\text { Page }}$

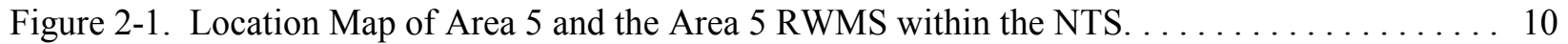

Figure 2-2. Orthophotography Showing Locations of GCD Boreholes in the Area 5 RWMS. . . . . 13

Figure 4-1. Controlled Area Around GCD Boreholes in the Area 5 RWMS . . . . . . . . . . 42

\section{TABLES}

$\underline{\text { Page }}$

Table 3-1 - Comparison of Assurance Provisions of 40 CFR 191 With DOE Order 5820.2A, Chapter III

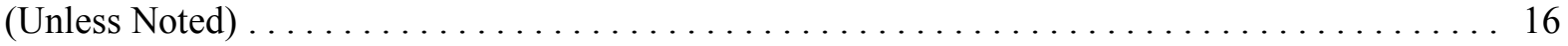

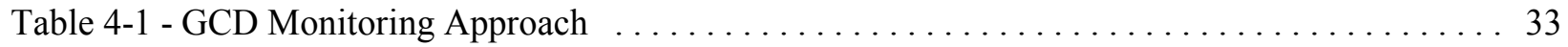

Table 4-2 - Expert Elicitation Estimates of Durability of Active Institutional Control . . . . . . . 35

Table 4-3 - Expert Elicitation Estimates of Durability of Site Knowledge . . . . . . . . . . . . . 40 


\section{ACRONYMS}

$\begin{array}{ll}\text { AIC } & \text { Active Institutional Controls } \\ \text { BLM } & \text { Bureau of Land Management } \\ \text { BN } & \text { Bechtel Nevada } \\ \text { CAD } & \text { Compliance Assessment Document (GCD) } \\ \text { CCA } & \text { Compliance Certification Application (WIPP) } \\ \text { CFR } & \text { Code of Federal Regulations } \\ \text { CR } & \text { Containment Requirements } \\ \text { D\&D } & \text { Decontamination \& Decommissioning } \\ \text { DOE } & \text { U.S. Department of Energy } \\ \text { DOE/DP } & \text { U.S. Department of Energy/Defense Program } \\ \text { DOE/NV } & \text { U.S. Department of Energy/Nevada Operations Office } \\ \text { DOI } & \text { U.S. Department of Interior } \\ \text { EIS } & \text { Environmental Impact Statement } \\ \text { EM } & \text { DOE Environmental Management } \\ \text { EPA } & \text { U.S. Environmental Protection Agency } \\ \text { FFACO } & \text { Federal Facility Agreement and Consent Order } \\ \text { FY } & \text { Fiscal Year } \\ \text { GCD } & \text { Greater Confinement Disposal } \\ \text { HLW } & \text { High-Level Waste } \\ \text { IHI } & \text { Inadvertent Human Intrusion } \\ \text { LLW } & \text { Low-Level Waste } \\ \text { LTS\&M } & \text { Long-term Stewardship and Maintenance } \\ \text { LWA } & \text { Land Withdrawal Act } \\ \text { MW } & \text { Mixed Waste } \\ \text { NEPA } & \text { National Environmental Policy Act } \\ \text { NRC } & \text { U.S. Nuclear Regulatory Commission } \\ \text { NTS } & \text { Nevada Test Site } \\ \text { NTTR } & \text { Nevada Test and Training Range } \\ \text { NWAR } & \text { Nuclear Weapons Accident Residue } \\ \text { PA } & \text { Performance Assessment } \\ \text { PEIS } & \text { Programmatic Environmental Impact Statement } \\ \text { PIC } & \text { Passive Institutional Controls } \\ \text { PMP } & \text { Program Management Plan } \\ \text { RCRA } & \text { Resource Conservation and Recovery Act } \\ \text { ROD } & \text { Record of Decision } \\ \text { RWMS } & \text { Radioactive Waste Management Site } \\ \text { SLB } & \text { Shallow Land Burial } \\ \text { SME } & \text { Subject Matter Expert } \\ \text { SNF } & \text { Spent Nuclear Fuel } \\ \text { TRU } & \text { Transuranic } \\ \text { VOC } & \text { Volatile Organic Compound } \\ \text { WIPP } & \text { Waste Isolation Pilot Plant } \\ \text { WM } & \text { Waste Management } \\ & \end{array}$




\subsection{Objectives and Scope of this Report}

This report describes how the U.S. Department of Energy (DOE) will comply with the Assurance Requirements specified in the Environmental Protection Agency (EPA) Standard for transuranic (TRU) waste disposal, 40 CFR 191 [EPA, 1985] as they apply to the Greater Confinement Disposal (GCD) boreholes located in the Area 5 Radioactive Waste Management Site (RWMS) in the Nevada Test Site (NTS). The GCD Compliance Assessment Document (the CAD, of which this Volume 4 is a part) is concerned with the requirements for disposal of TRU wastes buried in the GCD boreholes (specifically boreholes 1 through 4) in Area 5. Though an effort is made to address and ensure consistency with NTS-wide stewardship, closure and monitoring issues, this report is confined to the specific actions required to comply with the provisions spelled out in 40 CFR 191.

\subsection{Project Background}

DOE is responsible for disposing a variety of radioactive wastes, including certain by-product and naturally occurring materials, high-level wastes (HLW), spent nuclear fuel (SNF), TRU waste, and low-level waste (LLW). By-product and naturally occurring materials have historically been disposed by placing an earthen cover over the mounded tailings [Price, 1994]. Spent nuclear fuel consists of the fuel rods removed from a nuclear reactor following irradiation, the constituent elements of which have not been separated by reprocessing. HLW results from reprocessing of spent nuclear fuel. HLW and SNF, whether commercially generated or generated by defense activities, are to be disposed in the proposed HLW repository (the Yucca Mountain site in Nevada is currently under investigation for this repository). TRU waste is, in general, to be disposed in the Waste Isolation Pilot Plant (WIPP) near Carlsbad, New Mexico. TRU waste that does not meet the waste acceptance criteria for the WIPP is to be disposed by alternative methods (e.g., GCD boreholes). Traditionally, LLW has been disposed using near-surface shallow land burial (SLB) techniques at various DOE and commercial sites around the country.
TRU waste is DOE-titled radioactive waste "containing more than 100 nanocuries of alphaemitting transuranic isotopes, with half-lives greater than twenty years, per gram of waste, except for: 1) high-level radioactive wastes; 2) wastes that the U.S. Department of Energy has determined, with the concurrence of the EPA administrator, do not need the degree of isolation required by 40 CFR 191; or 3) wastes that the U.S. Nuclear Regulatory Commission (NRC) has approved for disposal on a case-by-case basis in accordance with 10 CFR 61." (40 CFR 191.02i).

From 1984 to 1987 , the DOE disposed a small quantity (about $125 \mathrm{~m}^{3}$ ) of TRU waste in GCD boreholes in the Area 5 RWMS at the NTS. This waste did not meet the waste acceptance criteria for WIPP because it is classified for national security reasons. DOE needs to determine whether the GCD boreholes at the NTS are an acceptable alternative method for disposal of these TRU wastes, and whether the GCD disposal method is protective of human health and the environment per the requirements of 40 CFR 191.

\subsection{Overview of Volume 4}

The balance of Section 1 provides a detailed summary of the regulatory requirements in $40 \mathrm{CFR}$ 191 that apply to the GCD boreholes, followed by a separate discussion and interpretation of the six Assurance Requirements from 40 CFR 191. A much more detailed summary of the regulatory requirements applicable to GCD is found in the CAD, Volume 2, Section 2. Recommendations and conclusions for compliance with the Assurance Requirements based on the analysis in this report are also summarized.

Section 2 provides a succinct description of the GCD boreholes that are part of the Area 5 RWMS of the NTS. This discussion provides a summary of existing NTS provisions for land ownership and control. Further details regarding site description can be found in the CAD, Volume 2, Section 5.

Section 3 provides a brief summary and description of closure plans and approaches that are anticipated for the Area 5 RWMS and the NTS. The GCD boreholes are part of the Area 5 RWMS 
which is used primarily for LLW SLB. The DOE requirements for burial of LLW in these facilities (DOE Order 5820.2A,[DOE, 1988]) are similar to the Assurance Requirements of 40 CFR 191 for TRU waste disposal. As such, Section 3 summarizes the requirements for disposal and closure of the Area 5 LLW facilities and compares these provisions with the Assurance Requirements. Much of the discussion in Section 3 relies to a large degree on reference to current provisions and plans under development for long-term landlord stewardship, operation, control, and closure of all facilities on the NTS.

\section{Key Long-Term Stewardship and Closure Documents}

\section{T Final EIS for the Nevada Test Site \\ $\mathrm{T}$ DOE/NV Resource Management Plan \\ $\mathrm{T}$ "Paths to Closure" Documents \\ T From Cleanup to Stewardship Report}

Section 4 summarizes the actions DOE will take to comply with the Assurance Requirements of 40 CFR 191 as they specifically apply to the TRU wastes in the GCD boreholes. Specific DOE actions and recommendations are provided. However, due to the long-term planning and implementation horizons involved, detailed design for certain assurance provisions will occur via updates to this report or in related future planning documents.

An Appendix to this Volume discusses the application of the 40 CFR 191 Assurance Requirements to the WIPP facility near Carlsbad, New Mexico, emphasizing the approach DOE took toward implementation of the Assurance Requirements. This discussion was included for two primary reasons: the GCD boreholes are subject to the identical set of Assurance Requirements, and application to WIPP provides an opportunity to understand EPA's interpretation of their Assurance Requirements. However, though subject to the identical set of Assurance Requirements in 40 CFR 191, WIPP represents a site with natural and engineered features, as well as waste characteristics and hazards, that differ dramatically from those present in the Area 5 RWMS. In addition, and of importance, WIPP was subject to direct review and certification by the EPA in accordance with provisions of the Land Withdrawal Act (LWA) and the criteria EPA established in 40 CFR 194 [EPA, 1996]. The EPA's 40 CFR 194 certification requirements were written specifically for WIPP and do not apply to other facilities attempting to demonstrate compliance with 40 CFR 191.

\subsection{Overview of Regulatory Basis for Assurance Requirements}

The regulations in 40 CFR 191, Subpart B, contain a number of quantitative and qualitative requirements that must be met to demonstrate adequate protection of human health and the environment from disposal of TRU wastes. The three quantitative requirements of Subpart B are the Containment Requirements (§191.13), Individual Protection Requirements (\$191.15), and Groundwater Protection Requirements (\$191.16); the Assurance Requirements ( $\$ 191.14)$ are more qualitative in nature. Assessing the safety of the TRU wastes emplaced in the GCD boreholes is based on comparing the results of quantitative performance assessments (PA) against the EPA requirements.

The Containment Requirements (CRs) are the most complicated of the three quantitative requirements. The CRs specify limits on the likelihood of exceeding certain release limits over 10,000 years. The design of disposal systems must provide a "reasonable expectation," based upon performance assessments, that the likelihood of cumulative releases over the 10,000-year regulatory time frame will not exceed the specified limits. However, complete assurance is not required because of the long periods of time involved, and the "substantial uncertainties" involved in projecting disposal system performance.

To provide more confidence that the CRs can be met, the EPA developed the qualitative Assurance Requirements as an equally important element of Subpart B. \$191.14 suggests that these requirements are needed to "provide the confidence needed for long-term compliance with the 
requirements of 191.13..." (in this case, for the disposal of TRU waste in the GCD boreholes). As such, the Assurance Requirements are meant to complement the CRs. Therefore, implementation of measures to meet the Assurance Requirements for any disposal system configuration should not be completed in isolation of the assessments used to determine compliance with the CRs. For example, if the performance assessment recognizes site and design features of the disposal system (such as physical barriers, whether natural or engineered) or administrative controls (such as land use restrictions), and takes credit for those provisions in meeting the CRs, then the disposal system design and the implementation of provisions to meet the Assurance Requirements should be consistent.

It is important to note, however, that the PA methodology provides assurance and a "reasonable expectation"-by defensible representation and treatment of uncertainty throughout the process - that the correct regulatory decision was made.

The methodology outlined in Section 3, Volume 2, of the CAD identifies, propagates, and systematically reduces uncertainty throughout the PA process. Uncertainty is considered and managed throughout the process rather than as a separate activity at the end of the PA. The scenario analysis provides assurance, by identifying the full suite of all significant processes and events. Addressing model uncertainty by concentrating on those models that could result in releases and screening models that have little or no impact (or that improve performance) provides assurance. If compliance can be demonstrated with all plausible models, then a high level of confidence in the decision to accept the site can be achieved. As the PA progresses, data and information are collected, if needed, to reduce parameter uncertainty (or, for that matter, to substantiate or refute model assumptions). The PA methodology provides confidence that if collection of additional information will result in lower estimated cumulative release or dose. Because of this handling of uncertainty throughout the process, new knowledge (such as that obtained through a monitoring program) will likely strengthen the original decision that the site is acceptable.

In contrast, in a deterministic PA process, there is a lack of assurance in the results because treatment of uncertainty is not part of the process. Therefore, additional assurance must be provided after the analysis is completed (in the form of monitoring provisions, for example).

\subsection{The Assurance Requirements}

The following subsections provide a more detailed discussion and interpretation of the six Assurance Requirements.

\section{The "Verbs" for Assurance}

- $\quad$ Site, to avoid resources

- Design, not to preclude future removal

- Isolate, wastes from man and environment

- Monitor, performance following disposal

- Prevent, access and restricted activities

- Warn, future generations of dangers

\subsubsection{Siting to Avoid Mined or Accessible Resources}

The disposal facility site selection process must consider the availability and accessibility of valuable resources, the extraction of which could disturb the buried waste and endanger the inadvertent intruder into the disposal facility.

\section{$\S 191.14(\mathrm{e})$ states the following:}

Places where there has been mining for resources, or where there is a reasonable expectation of exploration for scarce or easily accessible resources, or where there is a significant concentration of any material that is not widely available from other sources, should be avoided in selecting disposal sites. Resources to be considered shall include minerals, petroleum or natural gas, valuable 
geologic formations, and groundwaters that are either irreplaceable because there is no reasonable alternative source of drinking water available for substantial populations or that are vital to the preservation of unique and sensitive ecosystems. Such places shall not be used for disposal of the wastes covered by this part unless the favorable characteristics of such places compensate for their greater likelihood of being disturbed in the future. (emphasis added)

In promulgating this Assurance Requirement, EPA placed an emphasis on siting, design, and analysis that would provide better overall protection. Requiring implementing agencies to identify and avoid areas with significant resource potential provides a disincentive for siting in such areas, but at the same time does not suggest an outright prohibition of such site selection. Areas with significant resource potential can still be considered if their favorable characteristics for isolation of wastes from the accessible environment out-weigh the greater likelihood that the site may be disturbed through exploratory activities by humans in the future.

\subsubsection{Design for Future Removal of Waste}

The site and its design should not preclude the possibility of removing the wastes for a reasonable period of time following disposal.

\section{$\S 191.14(f)$ states the following:}

Disposal systems shall be selected so that removal of most of the wastes is not precluded for a reasonable period of time after disposal.

During the public comment period when the rule was being considered, inclusion of this Assurance Requirement suggested to some that making the waste relatively easy to retrieve might compromise the isolation capabilities of waste repositories (emphasizing instead, for example, the intrinsic value of the waste for future use). However, EPA made it clear in the rule that the intent of this provision was that recovery need not be easy or inexpensive but only possible. The closed repository must meet this requirement without any additional procedures or design features that specifically accommodate future removal of wastes. It must only be technologically feasible to remove the wastes. The intent, rather than to design a repository that is easy to mine in the future, is to call into question alternative disposal concepts that might not be so reversible. Future generations must have the option to correct any mistakes that this generation makes in generation and disposal of wastes.

\subsubsection{Isolate Via Engineered and Natural Barriers}

Barriers are needed to contain and isolate the wastes and to delay the movement of water and radionuclides toward the accessible environment. They can be a combination of natural and/or engineered barriers appropriate to the facility, its location, and the nature of the wastes.

$\S 191.14(\mathrm{~d})$ states the following:

Disposal systems shall use different types of barriers to isolate the wastes from the accessible environment. Both engineered and natural barriers shall be included.

EPA provides a specific definition in 40 CFR 191.12 (d): "Barrier" means any material or
structure that prevents or substantially
delays movement of water or
radionuclides toward the accessible
environment. For example, a barrier
may be a geologic structure, a cannister,
a waste form with physical and chemical
characteristics that significantly
decrease the mobility of radionuclides,
or a material placed over and around
waste, provided that the material or
structure substantially delays movement
of water or radionuclides. 
One of the primary concerns leading to the requirement for engineered and natural barriers is the reduction of risk given extremely poor performance of any single barrier. Thus, EPA has adopted the multiple barrier principle or "defense in depth." EPA puts an emphasis on "the best performance reasonably achievable" through such design principles and on site selection to provide the best isolation capabilities available.

\subsubsection{Monitor Post-Closure Performance}

Pre- and post-closure monitoring must be implemented based on site-specific considerations to assess any potential deviations from the expected performance of the waste disposal facility and the natural environment surrounding the facility.

$\S 191.14(b)$ states the following:

Disposal systems shall be monitored after disposal to detect substantial and detrimental deviations from expected performance. This monitoring shall be done with techniques that do not jeopardize the isolation of the wastes and shall be conducted until there are no significant concerns to be addressed by further monitoring.

"Expected performance" will be determined by performance assessments conducted to show compliance with the CRs. It will be up to the implementing agency (DOE) to define indicators and parameters that establish "substantial and detrimental deviations" as well as deviations that are no longer considered significant.

The monitoring requirement is consistent with the overall intent of the Assurance Requirements: to take prudent and cautious steps necessary to minimize risks posed by the large uncertainties inherent in assessments of performance. Monitoring, like the inclusion of barriers, was intended to guard against unexpected failures of the disposal system. However, at the same time, monitoring provisions must not jeopardize the isolation capabilities of the system being monitored. The intent is not to specifically detect radionuclide releases (which is unlikely in a reasonable time period following closure), but to monitor for parameters that improve the confidence that the system is behaving and performing as intended. An objective is to monitor without enhancing pathways for the wastes to escape or migrate to the human environment. The specific requirements for monitoring will depend on site characteristics, design, and performance; establishing and meeting the objectives of monitoring are the responsibility of the implementing agency.

Post-closure monitoring requirements for the GCD boreholes should be tied to the results of the PA and the parameters defined in that analysis that may be significant to system performance. However, as noted in the CAD, Volume 2, Section 8.2 , uncertainty about system performance is controlled by uncertainty in the PA models. The results of the model support a compliance decision and do not necessarily mimic performance of the real system. Therefore, care is required in the design of an appropriate monitoring scheme.

\subsubsection{Prevent With Active Institutional Controls (AICs)}

The AICs control access to and use of the disposal facility through various means (security force, fences, signs, land reclamation, land-use restrictions and control, periodic surveillance and maintenance, monitoring).

$\S 191.14(a)$ states the following:

Active institutional controls over disposal sites should be maintained for as long a period of time as is practicable after disposal; however, performance assessments that assess isolation of the wastes from the accessible environment shall not consider any contributions from active institutional controls for more than 100 years after disposal.

EPA provides a specific definition in 40 CFR 191.12 (f):

"Active institutional control" means (1) 
Controlling access to a disposal site by any means other than passive institutional controls, (2) performing maintenance operations or remedial actions at a site, (3) controlling or cleaning up releases from a site, or (4) monitoring parameters related to disposal system performance.

Practically, EPA expects the implementing agency (DOE) to institute such active controls for long periods of time (ideally, for the entire 10,000-year regulatory time frame). However, EPA also recognized that "...the institutional controls designed to reserve this area around a disposal system cannot be considered infallible...," thus the need to establish the limit, for quantification of risks, of 100 years for effective controls. The latter period of time can be clearly established when quantifying the performance of the system toward assessing compliance with the CRs. However, in the former case, the DOE will still need to establish administrative, policy, legal, and financial provisions to meet the intent of this section of the Assurance Requirements; that is, that the controls are maintained in place as long as practicable.

\subsubsection{Warn Via Passive Institutional Controls}

Passive institutional controls (PICs) can include permanent markers or placards denoting the boundaries of the site and warnings of the hazards contained within, extensive records and archives documenting the facility and its hazards, government ownership and control of the land and facility, and other means to maintain knowledge of the site for future generations.

§191.14(c) states the following:

Disposal sites shall be designated by the most permanent markers, records, and other passive institutional controls practicable to indicate the dangers of the wastes and their location.

The use of passive institutional controls is assumed and embodied in the definition of the controlled area:
Controlled area means (1) A surface location, to be identified by passive institutional controls, that encompasses no more than 100 square kilometers and extends horizontally no more than five kilometers in any direction from the outer boundary of the original location of the radioactive wastes in a disposal system; and (2) the subsurface underlying such a surface location (§191.12g). (emphasis added)

Specific means of implementing such controls are suggested in another definition in the rule:

"Passive institutional control" means (1) Permanent markers placed at a disposal site, (2) public records and archives, (3) government ownership and regulations regarding land or resource use, and (4) other methods of preserving knowledge about the location, design, and contents of a disposal system (§191.12e).

The Preamble of 40 CFR 191 provides a clear discussion of the rationale EPA used to develop the requirements for passive institutional control. As opposed to the shorter period of time assumed for viable active institutional controls, EPA suggests that DOE may rely upon effective implementation of passive institutional controls for a greater period of time (e.g. several hundreds of years). Such controls should reduce (but not eliminate) the likelihood of inadvertent human intrusion (IHI) compared to the likelihood of such intrusion if no markers and records were put in place. EPA assumes that the Federal government is committed to retaining ownership of all disposal sites and will establish appropriate markers and records to deter intrusion into those sites for as long as practicable. The agency has assumed that society in general will retain knowledge about buried wastes and that future societies will be able to deter systematic or persistent exploration of the disposal site.

The EPA recognized that institutional controls, active or passive, cannot be relied upon to completely eliminate the possibility of IHI. Assessing possible human exploration and IHI, and the effectiveness of active and passive controls to 
Introduction

deter such exploration near a disposal facility, would entail informed judgement and speculation regarding future human activities. Therefore, EPA has pursued standards that emphasize the physical characteristics of disposal system siting and design for the very long periods of time under consideration, rather than excessive reliance on long-term maintenance and surveillance. Appendix B of 40 CFR 191 provides parameters and guidance on the likelihood and possible consequences of IHI that EPA assumed were the most pessimistic in making performance assessments. It is assumed that exploratory drilling for resources is the most severe intrusion scenario, and that passive institutional controls or the intruders own exploratory activities are adequate for detection and warning of the dangers in the area. EPA provides guidance on the rate of such intrusions (e.g., the number of random, exploratory boreholes per square kilometer over 10,000 years) as well as the consequences of such exploration.

\subsection{Recommendations and Conclusions}

Below is a summary of actions DOE will take in order to comply with the 40 CFR 191 Assurance Requirements.

\section{$\underline{\text { Site, to Avoid Resources }}$}

No actions are needed to demonstrate compliance with this Assurance Requirement. DOE concludes that the very favorable characteristics of the GCD site (as demonstrated in the PA analysis in Volume 2 of the CAD) more than compensate for the very low likelihood of future disturbance of the waste due to human activities that might involve drilling for water underlying the Area 5 RWMS. See subsection 4.1 for detailed discussion.

\section{Design, Not to Preclude Future Waste Removal}

No actions are needed to demonstrate compliance with this Assurance Requirement. DOE concludes there is no need for extensive plans, design provisions, or efforts to demonstrate the technical feasibility of future waste removal from the GCD boreholes. See subsection 4.2 for detailed discussion.

\section{Isolate Wastes Using Effective Barriers}

No actions are needed to demonstrate compliance with this Assurance Requirement. The GCD facility utilizes simple, yet very effective natural barriers to ensure isolation of the disposed wastes from the accessible environment. The results of the PA demonstrated compliance with the CRs of 40 CFR 191. Therefore, DOE has determined that there are no further analyses required at this time to demonstrate compliance with the intent of this Assurance Requirement. However, DOE/NV intends to include engineered barriers in the final assessments and closure plan for the GCD boreholes. See subsection 4.3 for detailed discussion.

\section{Monitor Performance Following Disposal}

DOE is currently monitoring a number of key parameters associated with waste disposal operations in the Area 5 RWMS, which contains the GCD boreholes. Any additional monitoring of the GCD boreholes to demonstrate compliance with the Containment and Assurance Requirements of 40 CFR 191 will be planned and conducted consistent with current monitoring activities. DOE intends to continue monitoring the vadose zone surrounding the GCD boreholes to verify moisture contents and movement of moisture assumed in the $\mathrm{PA}$, and the absence of radionuclides during the monitoring period. The nature and extent of plant and animal bioturbation will be measured and observed; closure cap performance monitoring will verify the integrity of the cap; and the nature and extent of subsidence (and mitigation efforts) will be measured, monitored, and documented. See subsection 4.4 for detailed discussion.

\section{$\underline{\text { Prevent Access and Restricted Activities }}$}

An NTS-wide program of Active Institutional Controls currently exists and will be maintained for the foreseeable future. As operations in the Area 5 RWMS cease and disposal facilities are closed during the next 70 years, the AICs in this area will be upgraded consistent with DOE plans for longterm stewardship of the NTS. Long-term land ownership and control agreements with various agencies of the United States government will be 
maintained for the foreseeable future to support current and future missions of the NTS. Unauthorized activities will be prevented and/or controlled. As necessary, DOE will implement land use controls and permits, access control measures and security, and fences and signs to protect facilities against unauthorized access and use. During active control, DOE will perform necessary maintenance, remedial actions, and decommissioning steps needed to establish proper post-closure conditions for the site. See subsection 4.5 for detailed discussion.

\section{$\underline{\text { Warn Future Generations of Dangers }}$}

The anticipated time horizons for active operation of the Area 5 RWMS, LLW facilities, and other DOE Defense Program operations until at least FY 2070 will delay the need for actual implementation and placement of Passive Institutional Control provisions applicable to the GCD boreholes. As such, over time DOE will develop a plan to design and implement the PICs that are appropriate, practical, and effective for long-term passive control of the Area 5 RWMS and GCD boreholes. The PICs will include markers and monuments to demark the controlled area boundary, Area 5 RWMS, and the GCD boreholes, as well as records that define the location, design, content and hazards of the GCD boreholes. See subsection 4.6 for detailed discussion. 


\subsection{Site/Facility Description}

This section provides a brief description of the NTS and GCD boreholes, with emphasis on current site configuration and provisions for access control and maintenance of security, operational control, and long-term monitoring. Refer to the CAD, Volume 2, Section 5 for a detailed description of the GCD boreholes and the Area 5 RWMS. Also refer to the NTS site-wide Environmental Impact Statement (EIS) [DOE, 1996a] for site descriptions and more detailed summaries of facilities, procedures, and plans for long-term management of the site. In addition, the DOE/NV Resource Management Plan [DOE, 1998c] summarizes the status of and future plans for NTS-wide resource management and utilization, data management, monitoring provisions, and adaptive management for the site in support of its various missions.

\subsection{The Nevada Test Site}

The NTS is a DOE Environmental Research Park located on federally owned (Bureau of Land Management or BLM) land in Nye County in southeastern Nevada approximately 105 km (65 mi) northwest of Las Vegas (see Figure 2-1). The NTS encompasses $3,561 \mathrm{~km}^{2}\left(1,375 \mathrm{mi}^{2}\right)$ of land reserved to the jurisdiction of the DOE for use as a weapons testing site. The site is bordered to the west, north, and east by the Nevada Test and Training Range (NTTR, also known as Nellis Air Force Base), another government-owned area with restricted access. The lands are mostly undeveloped. Nuclear weapons testing has been the primary mission of the NTS since the first test in January 1951.

The NTS varies in elevation from approximately 914 to $2345 \mathrm{~m}$ (3,000 to 7,694 ft) above sea level. The NTS is in the southern part of the Basin and Range Physiographic Province which is characterized by north-to-northwest trending mountains separated by basins. The NTS is part of the Great Basin Mojave Desert Region, an area where the climate ranges from arid to semiarid, with cold winters and hot summers. Within or part of the NTS are the Yucca Mountain site (in the southwestern portion), Yucca Flat, and Frenchman Flat. Yucca Flat and Frenchman Flat are in closed, fault-bounded, alluvium-filled basins that are typical of the southern Basin and Range Province.
Both basins are located in the eastern part of the NTS, and portions of each were used over a period of 40 years for underground nuclear testing.

This land area has been withdrawn from all forms of appropriation under public land laws. It was created through issuance of Public Land Orders and the Federal Land Policy and Management Act of 1976. Memoranda of Understanding and Agreements between DOE, the U.S. Air Force (regarding shared use of the NTTR), and DOE Yucca Mountain Site Characterization Office also control use and access for specified purposes.

Improved land-use decisions are expected through development of a Five-Party Agreement with the DOE, the NTTR, the BLM, U.S. Fish and Wildlife Service, and the State of Nevada. "The transition of the NTS from an active underground nuclear weapons testing program to a program of stewardship of the enduring nuclear stockpile and test readiness has provided the opportunity to make portions of the NTS available for alternate uses." [DOE 1998c] These parties will meet annually to share information and discuss issues of mutual concern. A Site Use and Development process, Board, and Working Group will coordinate decisions regarding site use and resource management. "Their purpose is to review proposed activities that will occur on the NTS and to rule out activities not appropriate for DOE/NV facilities or that cannot meet customer needs." For instance, three major use zones have been established: the National Security Use zone, a Restricted Use zone, and a General Use zone. Buffer zones are established to ensure incompatible activities do not impact NTS missions. Projects are screened to ensure they support the national interest and current DOE programs.

\subsection{Current NTS Access Control Provisions}

Due to its past and anticipated future missions in support of operational readiness and nuclear weapons testing, DOE and the United States government have committed to oversight and management of the NTS for the foreseeable future. 


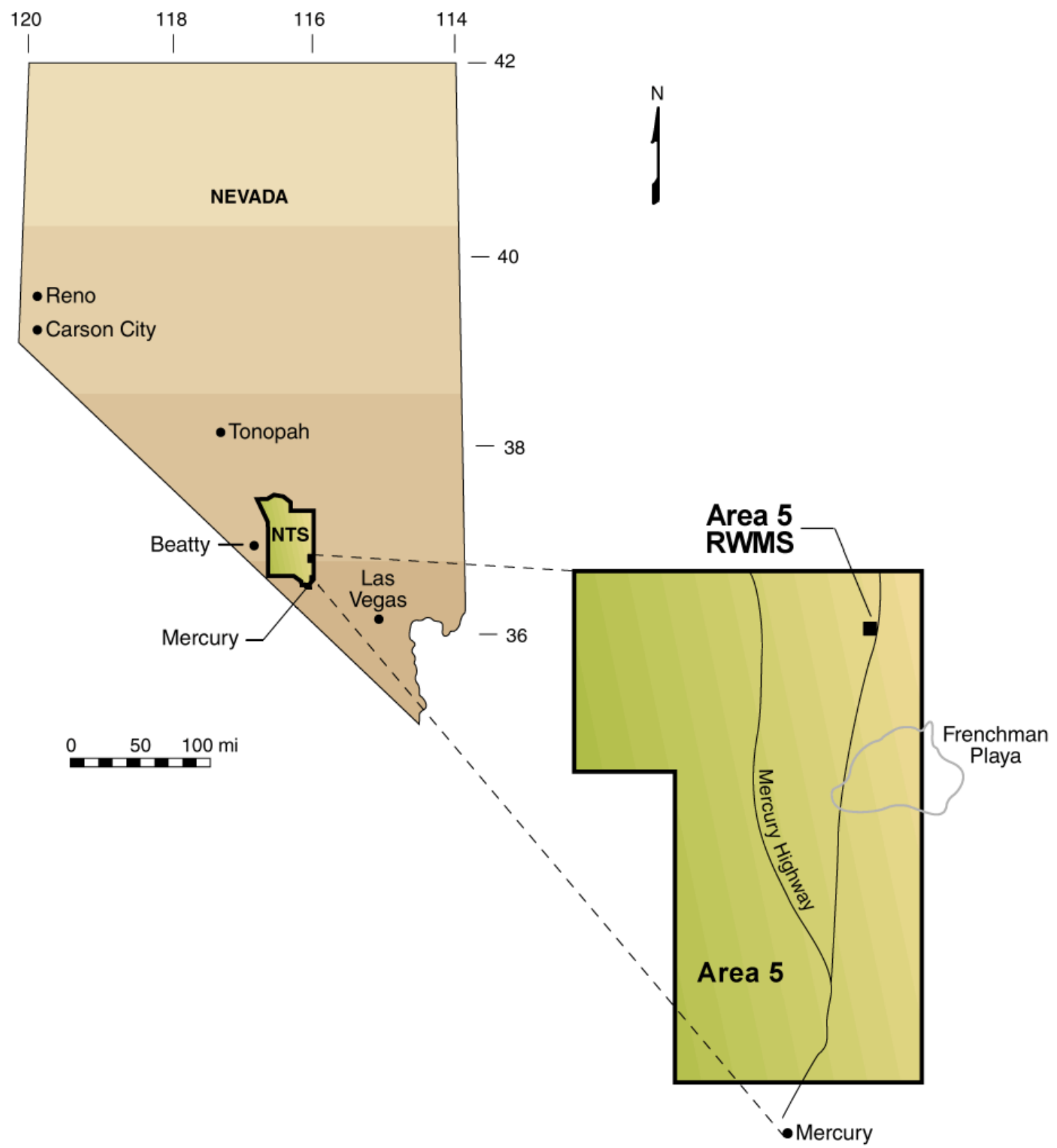

Figure 2-1. Location Map of Area 5 and the Area 5 RWMS within the NTS.

The following 4 paragraphs are taken directly from the Resource Management Plan.

The NTS is surrounded by governmentcontrolled buffer zones and protected by Security Police officers, mobile patrols, and highly-trained emergency response teams. Sensitive areas within the NTS use chain-link fencing, protective alarms, closed-circuit television, and secure communications systems. The
Nye County Sheriff's Department provides civil law enforcement.

The NTS is a controlled-access area with road access beginning at the Security Station on Mercury Highway, 5 miles from the US Highway 95 Mercury turnoff. Although a security clearance is not required for entry, access is not allowed without proper identification and an identification badge. Personnel 
Site/Facility Description

are issued dosimetry badges if entering areas where they might be exposed to radiation levels above background. Security areas within the NTS have stringent personnel controls, requiring the appropriate security clearance and an operational need before access is allowed.

The entire perimeter of the NTS is not fenced, but it is posted as a restricted area; access is prohibited except at designated entrances. Beyond the perimeter, the BLM and NTTR provide buffer zones. Barricades and/or Security Stations control the few roads that access NTS boundaries. Perimeter barricades are checked by security force patrols.

Inactive facilities and areas that are known to be contaminated and require access control are fenced and posted with warning signs. In remote areas where personnel rarely perform work activities, appropriate posting at the perimeter boundary as well as access roads to the contaminated area may be substituted instead of fencing. Further program enhancement is accomplished by following the Integrated Safety Management guiding principles and core functions.

\subsection{Radioactive Waste Management Sites}

There are two principal waste management sites at the NTS: the Area 3 RWMS and the Area 5 RWMS. The Area 3 RWMS contains three disposal cells that have either been filled or are being filled [U-3ax/bl (filled), U-3ah/at (being filled), and U-3bh (being filled)]. In addition, two subsidence craters (created by underground nuclear weapon testing) are available to receive waste. Two disposal cells are comprised of two subsidence craters (U-3ax/bl and U-3ah/at); one disposal cell is an individual crater (U-3bh). There are no GCD boreholes within Area 3.
Area 5 at the NTS was the site of some of the very early atmospheric tests in the 1950 's. The Area 5 RWMS (located in the northeast corner of Area 5), used since 1961, was officially designated in 1977 to serve as a waste consolidation site for NTS onsite, and offsite, waste generators. The RWMS became the principal disposal site for LLW generated at the NTS and for approximately 15 other DOE sites where no waste disposal capability existed. Until May 1990, mixed waste (MW) was disposed of in a separate cell under Resource Conservation and Recovery Act (RCRA) interim status. In addition, TRU waste was accepted for interim storage prior to shipment to the WIPP. The RWMS encompasses an area of approximately 2.96 $\mathrm{km}^{2}$ (732 acres) which are allotted for waste storage and disposal, and hazardous waste accumulation. There is currently an operational area within this RWMS of approximately $0.37 \mathrm{~km}^{2}$ (92 acres). The GCD boreholes are located within this 92-acre operational area.

After almost 40 years of waste disposal operations, monitoring has not detected any contamination of the groundwater near the Area 5 RWMS. In addition, field studies conducted to support the performance assessment models, which include monitoring of soil moisture and chloride ion concentrations, indicate that under current climatic conditions water falling on the surface (precipitation) in Frenchman Flat does not reach the groundwater. These studies and the absence of contamination support the conclusion that no groundwater pathway exists beneath the Area 5 RWMS. Thus, no impact to groundwater from waste management operations would be expected to occur. After shutdown, monitoring and security functions on the NTS would be reduced and become part of the sitewide monitoring activity.

The DOE is developing a comprehensive environmental management systems approach to ensure long-term protection from all sources of radioactive materials left in the ground after remediation and disposal programs are completed. The comprehensive approach will include requirements that integrate DOE's land-use planning, facility decommissioning, environmental restoration, and waste disposal efforts. Specifically, the long-term radioactive impact of 
waste disposal operations will be analyzed by combining performance assessments under DOE Order 5820.2A for the post-1988 waste source term, with a "Composite Analysis" of the pre-1988 waste source terms, as well as other sources of radioactive contamination in the ground that potentially interact with contamination originating from the LLW facility. The composite analysis serves as a long-term management planning tool.

\subsection{Greater Confinement Disposal Boreholes}

Greater confinement burial was adopted as a concept in 1981 by the DOE for wastes that are not appropriate for near-surface disposal due to the radioactive exposure levels from the waste. There are 13 GCD boreholes. Nine of the boreholes have been used for waste disposal. These nine GCD boreholes contain mixed waste; low-level waste; waste similar to greater-than-Class $\mathrm{C}$ low-level waste; and transuranic and transuranic mixed wastes. Specifically, these waste types include certain high-specific-activity LLW (for example, fuel rod claddings and sealed sources), and some classified wastes. Approximately $9.3 \times 10^{6} \mathrm{Ci}$ of high-specific-activity waste, primarily tritium, have been disposed in GCD units at the Area 5 RWMS. GCD borehole disposal ceased in 1989.

The GCD boreholes are not a separate entity with specifically designated boundaries. The GCD boreholes are located in a secured area within the operational portion of the Area 5 RWMS (see Figure 2-2). The four TRU-containing GCD boreholes are within a secondary enclosure for classified waste with its own access control provisions. Bechtel Nevada (BN) has established a program of visitor and access control procedures for the RWMSs and facilities within those sites. The secured area containing the GCD boreholes is also currently being used for disposal of LLW in trenches and pits.
Each of the GCD boreholes are unlined, 3.0- or $3.65 \mathrm{~m}(10-$ or $12-\mathrm{ft})$ in diameter, and augered to a depth of $36.5 \mathrm{~m}(120 \mathrm{ft})$ into the unsaturated alluvial fan deposits. The bottom of each borehole is approximately $198 \mathrm{~m}(650 \mathrm{ft})$ above the water table. Wastes were restricted to the lower $15.2 \mathrm{~m}$ $(50 \mathrm{ft})$ of each borehole (i.e. the top of the waste is $21.3 \mathrm{~m}(70 \mathrm{ft})$ below the land surface), and the borehole was then backfilled with the native alluvium to the top. Of the 9 boreholes that contain wastes, 7 have been filled and backfilled, and 5 contain classified wastes [Chu and Bernard, 1991; Price and Duran, 1994]. All of the boreholes (1-4) in the scope of this report are closed and contain classified TRU wastes. Boreholes 1-3 contain nuclear weapons accident residue (NWAR) which is also classified TRU waste. These wastes are packaged in plywood and metal boxes, and in metal barrels. The plywood boxes are coated with fiberglass. Probertite was used to backfill around the packages. Borehole 4 contains TRU waste from other sources. Most of these wastes are in fiberboard containers which were bagged in heavy plastic and placed inside 55-gallon drums.

No cap or other engineered barrier has been installed as of yet. DOE Order 5820.2A [DOE, 1988] extends the mandate for protective covers at landfills (such as those within the Area 5 RWMS for LLW disposal), which were established by the EPA through RCRA, to LLW trenches and pits. The performance goals of RCRA for protective covers are to 1) provide long-term minimization of liquid migration, 2) function with a minimum of maintenance, 3) promote drainage and minimize erosion or abrasion to the cover, 4) accommodate settling and subsidence, and 5) have permeability less than or equal to any bottom liner system or the natural subsoils present. Because of the location of the GCD boreholes within the RWMS, the protective cover for the RWMS will also cover the GCD boreholes. The closure plan for the RWMS is in the early stages of development (see Section $3)$. 


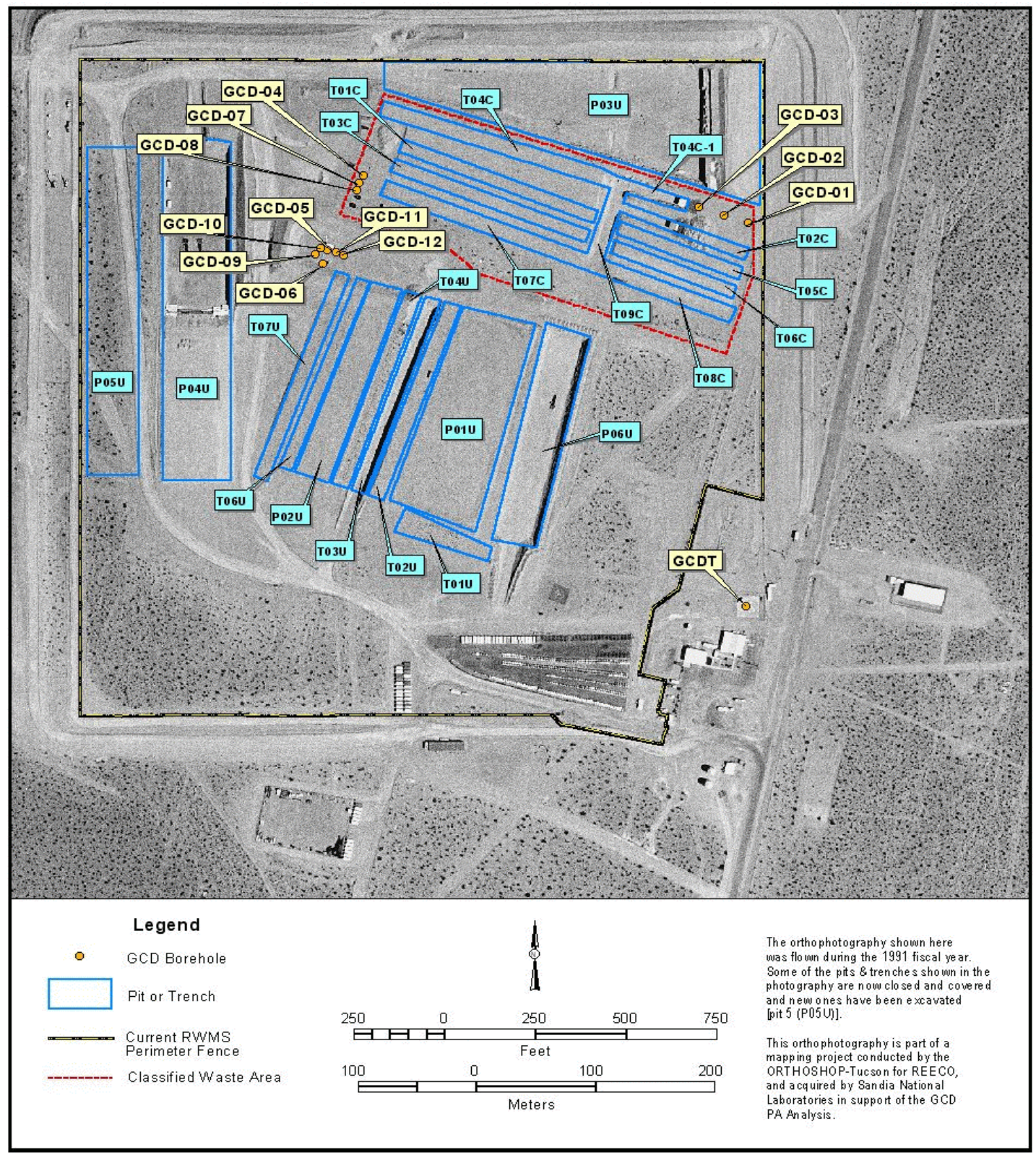

Figure 2-2. Orthophotography Showing Locations of GCD Boreholes in the Area 5 RWMS. 
This page intentionally left blank. 
The purpose of this section is to summarize anticipated DOE activities on the NTS for closure and long-term stewardship of waste disposal facilities, and to compare those provisions with activities needed to meet the 40 CFR 191 Assurance Requirements. Section 3.1 summarizes and compares the DOE Order-based closure requirements and closure plans for the Area 5 RWMS LLW disposal units. Section 3.2 summarizes a number of key DOE documents that discuss DOE plans and actions to establish "paths to closure" and long-term stewardship of their facilities nationwide. The focus here is on the plans for the NTS.

\subsection{Closure Requirements for LLW in the Area 5 RWMS}

Closure of the Area 5 RWMS LLW disposal units (pits, trenches and GCD boreholes) must meet the requirements of 40 CFR 265 (Pit 3 only) and Chapters III and V of DOE Order 5820.2A. Chapter III provides requirements for all aspects of LLW management, including generation, treatment, characterization, performance assessment, establishing acceptance criteria, site selection, site design, disposal facility operations, disposal, closure and post-closure, and monitoring. The regulations in $5820.2 \mathrm{~A}$ provide both quantitative performance objectives as well as the more qualitative requirements similar to the Assurance Requirements of 40 CFR 191. Chapter $\mathrm{V}$ establishes requirements for decommissioning all disposal facilities under DOE ownership and control, including LLW- and TRU- containing facilities.

DOE Policy 450.3 (enacted January 25, 1996) established a voluntary "necessary and sufficient" (also known as "Work Smart Standards") process that allows DOE Elements to tailor DOE orders and other standards and regulations to specific work and hazards associated with that work. $\mathrm{DOE} / \mathrm{NV}$ is currently implementing that process. As such, though DOE Order 435.1 replaced DOE Order 5820.2A on July 9, 1999, DOE/NV management made the decision to continue to comply with DOE Order 5820.2A, not DOE Order
435.1 [DOE, 1999a]. See Volume 2 of the CAD, Section 2.2 for more details on the necessary and sufficient process.

\subsubsection{Regulatory Evaluation and Comparison}

Table 3-1 provides a comprehensive side-by-side summary of the assurance provisions of Chapter III of DOE Order 5820.2A compared against the Assurance Requirements of 40 CFR 191. The contents of this comparison table are discussed in the following subsections pertaining to each of the six Assurance Requirements of 40 CFR 191.

\subsubsection{Active Institutional Controls}

The chapter of the DOE Order for LLW disposal provides little detail for active institutional control requirements for LLW disposal units beyond a definition and implicit reference to the control period for the termination of monitoring. The 40 CFR 191 requirements and the related discussions in the Standard and EPA Guidance are more comprehensive and form the basis for closure of the GCD boreholes. The AICs will also apply to the LLW disposal units.

\subsubsection{Monitoring}

The monitoring provisions of DOE Order 5820.2A Chapter III (for LLW disposal) are comprehensive and consistent with the monitoring requirements of 40 CFR 191 (for TRU waste disposal). Monitoring is defined as "The making of observations and measurements to provide data to evaluate the performance of a waste management operation" (Attachment 2, §21). A buffer zone is established that is "The smallest region beyond the disposal unit that is required as controlled space for monitoring and for taking mitigative measures..." (Attachment 2, §2). This section of the LLW monitoring program requirements provides specific guidance on the parameters to be monitored (i.e., migration and release of radionuclides, subsidence, parameter changes indicative of performance, soil, air, and water); this guidance is consistent with the monitoring requirements that apply to the TRU wastes in the GCD boreholes. 


\begin{tabular}{|c|c|c|}
\hline 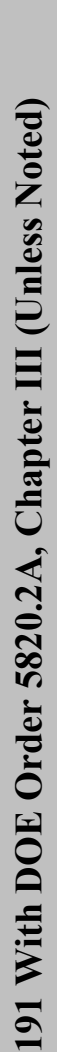 & 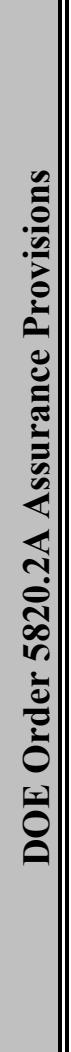 & 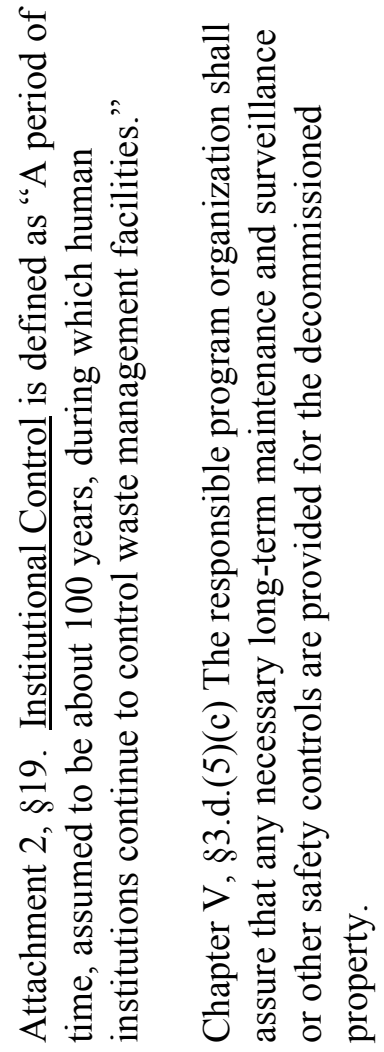 \\
\hline 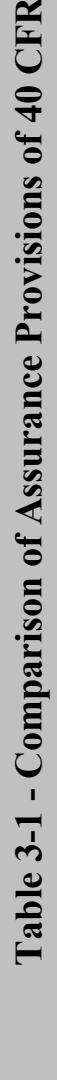 & 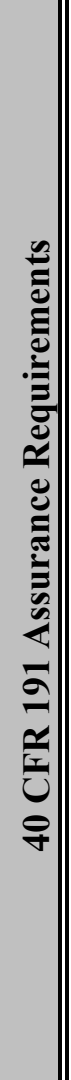 & 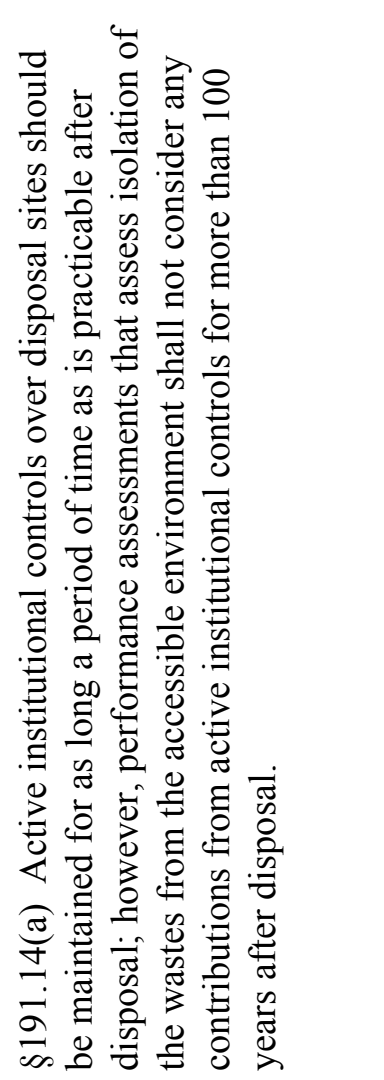 \\
\hline
\end{tabular}




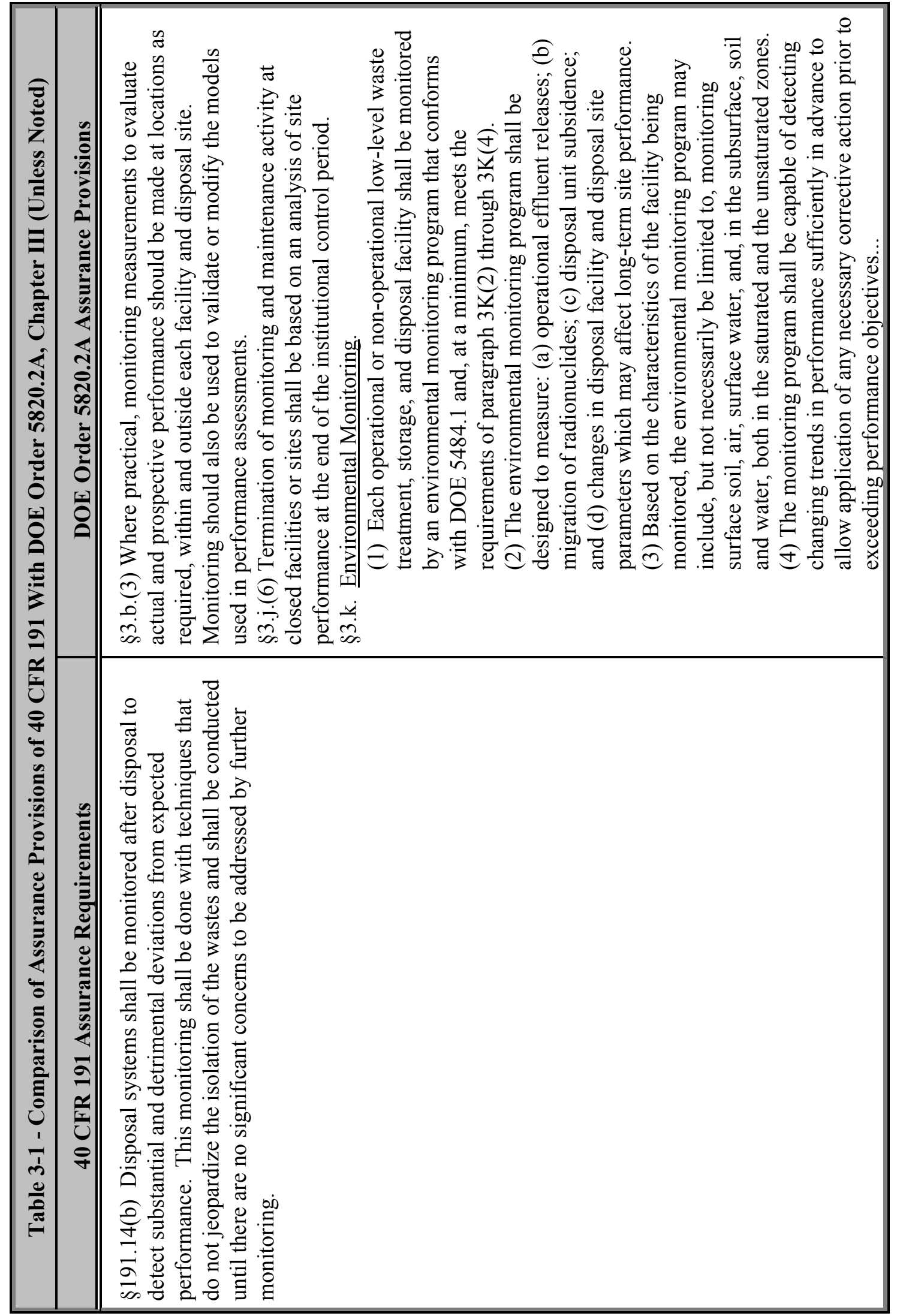




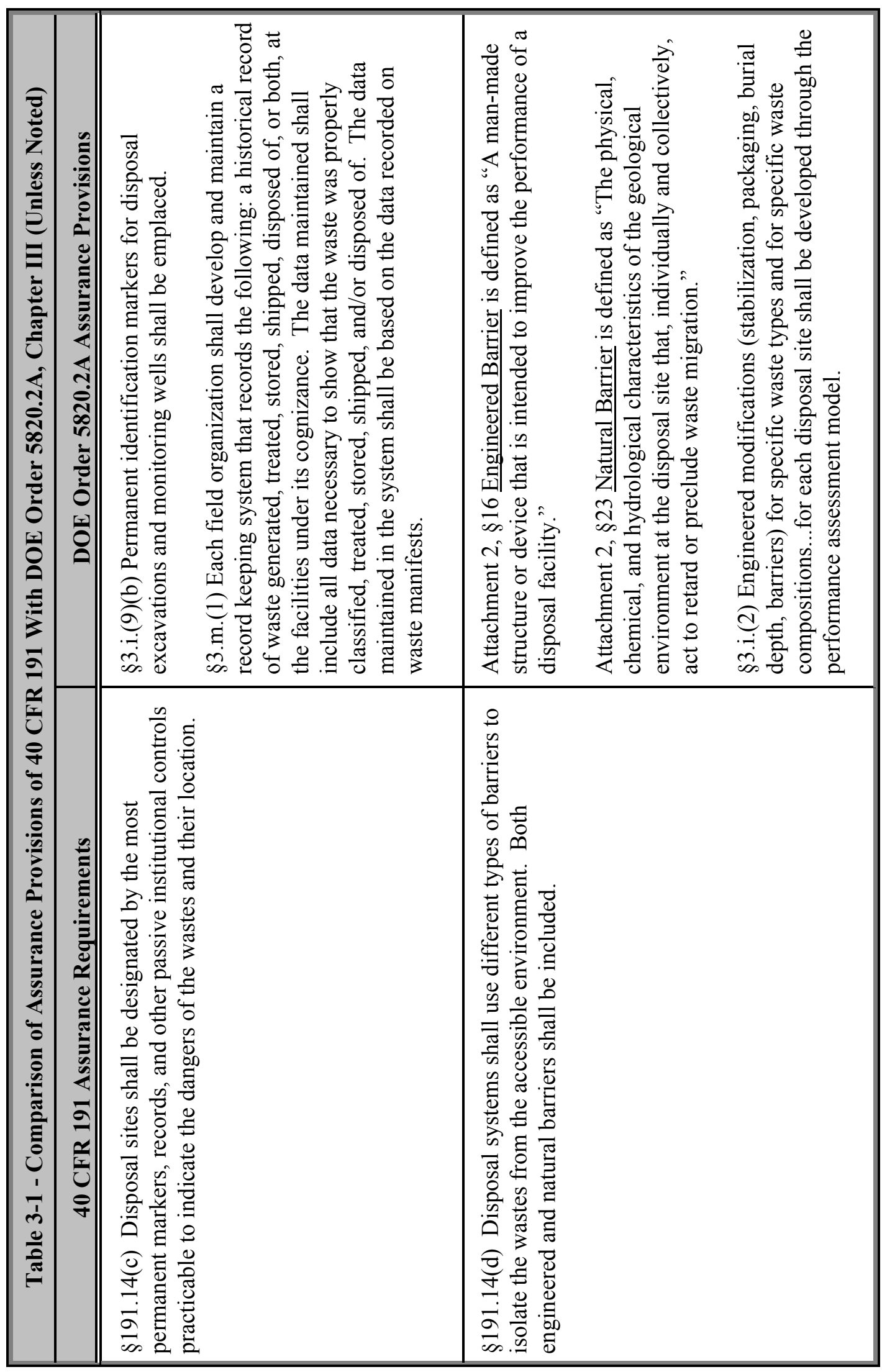




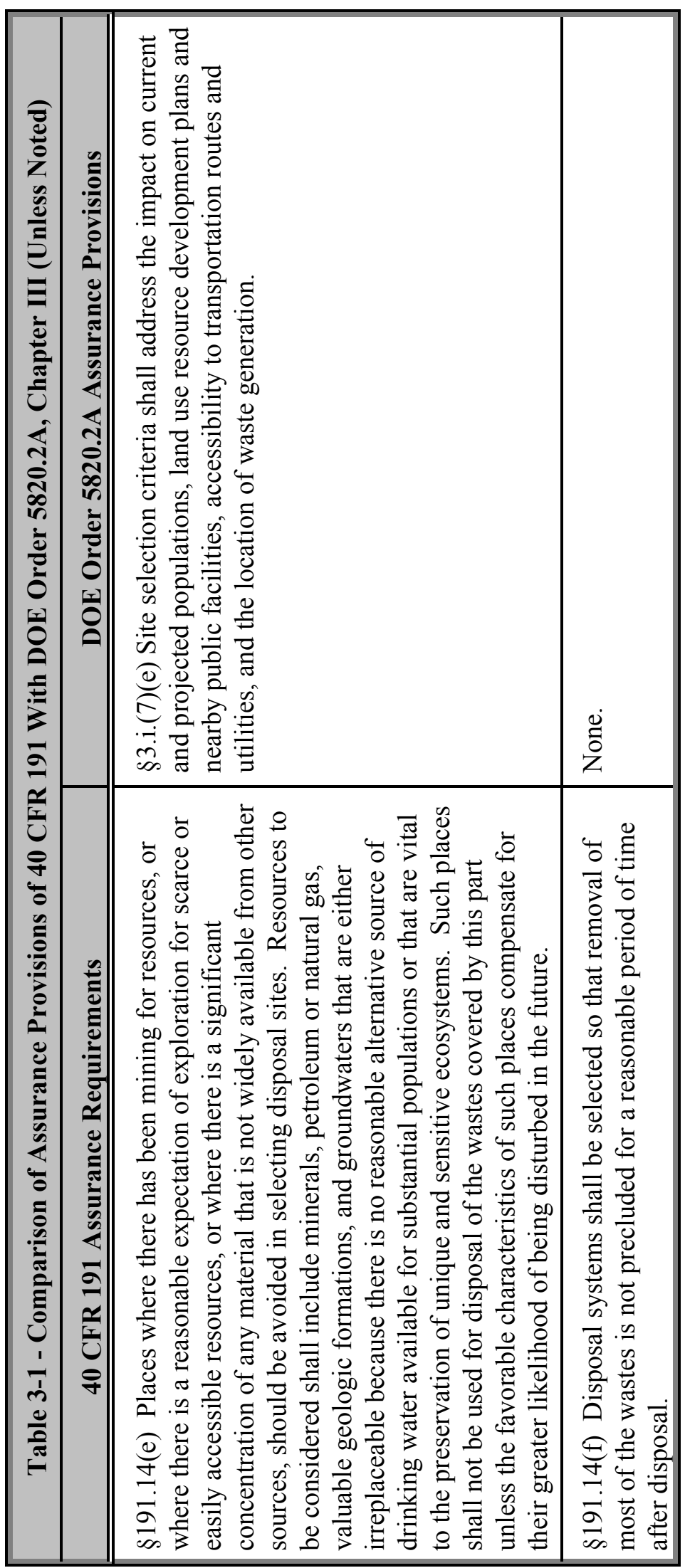




\subsubsection{Passive Institutional Controls}

As with active institutional controls, the requirements for passive control provisions (markers and placards, records and archives, land ownership and control) are brief in Chapter III of DOE Order 5820.2A. No guidance is provided for permanent marker design or specific placement requirements near the LLW disposal units. The distribution of record sets is not specified; only general records management requirements are provided. The 40 CFR 191 requirements, and particularly the discussions in the preamble of the Standard as well as the EPA Guidance, are more comprehensive and form the basis for the closure of the GCD boreholes.

\subsubsection{Barriers}

Chapter III only specifies that barriers be included in engineered modifications for LLW disposal units developed in the PA models. Definitions are provided for both engineered and natural barriers, consistent with 40 CFR 191. Discussions in the preamble to 40 CFR 191 address both requirements and EPA intentions with respect to natural and engineered barriers; as such, the EPA Standard is more comprehensive and forms the basis for the closure of the GCD boreholes.

\subsubsection{Site Selection and Resources}

The requirements in Chapter III for consideration of valuable and accessible resources in LLW site selection are only briefly discussed. Therefore, the 40 CFR 191 requirements with respect to site selection to avoid valuable resources are more comprehensive and form the basis for the closure of the GCD boreholes.

\subsubsection{Future Waste Removal}

There are no requirements in DOE Order 5820.2A for future removal of LLW from disposal units at the Area 5 RWMS. Therefore, the 40 CFR 191 requirements for future waste removal form the basis for the closure of the GCD boreholes.

\subsubsection{Closure Plan for the Area 5 RWMS LLW Disposal Units}

Chapter III of DOE Order 5820.2A provides specific requirements for closure plans that must be developed and implemented at DOE LLW disposal sites:

Field organizations shall develop sitespecific comprehensive closure plans for new and existing operating low level waste disposal sites. The plan shall address closure of disposal sites within a five-year period after each is filled and shall conform to the requirements of the National Environmental Policy Act process. Performance objectives for existing disposal sites shall be developed on a case-by-case basis as part of the National Environmental Policy Act process (§3.j.(1)).

The Order provides two closure definitions:

Operational Closure. Those actions that are taken upon completion of operations to prepare the disposal site or disposal unit for custodial care, (e.g., addition of cover, grading, drainage, erosion control) (\$5.a., Attachment 2).

Final Site Closure. Those actions that are taken as part of a formal decommissioning or remedial action plan, the purpose of which is to achieve long-term stability of the disposal site and to eliminate to the extent practical the need for active maintenance so that only surveillance, monitoring, and minor custodial care are required (§5.b., Attachment 2).

Bechtel Nevada and DOE/NV develop long-term baseline planning documents for the DOE/NV Waste Management Division, the current document spanning the period from FY 2000 to FY 2070. Specific dates are established for termination of TRU, MW and LLW activities. Closure covers for the existing Area 5 disposal facilities are planned to be completed by FY 2010. After that, waste operations in other operational areas of the Area 5 RWMS will be conducted by the DOE Defense Programs (DP) as "landlord" and steward of the 
facilities. Long-term closure of the entire Area 5 RWMS is currently scheduled to occur by FY 2070, after which active institutional control measures will begin.

Responsive to Chapter III of DOE Order 5820.2A, $\mathrm{DOE} / \mathrm{NV}$ is developing a site-specific closure plan for the Area 5 RWMS that will take into consideration the climate, geology, surface water and regional hydrology, and waste forms. This closure plan will investigate the optimum design for successful closure integrity in the arid NTS environment. Closure of the Area 5 RWMS will not occur until after the end of the active life of this area. Closure performance standards include:

- Minimizing maintenance requirements;

- Protection of human health and the environment;

- Minimizing or eliminating contaminant release; and

- Complying with applicable regulations and DOE Orders.

The current closure program for the NTS Area 5 RWMS is described in the Integrated Closure and Monitoring Plan for the Area 3 and Area 5 RWMSs [Bechtel Nevada, 2000]. The Area 5 RWMS is anticipated to be closed in four phases, each corresponding to a specific block of the waste disposal units. The four blocks, in the order of their closure, are the West, the South, the North, and the integration of these blocks. The GCD facility is within the North Block.

Closure activities for the various pits, trenches, and boreholes may include the following, in general:

- When waste is received and emplaced in trenches or pits, a temporary soil cover of clay and other fine-grained materials is used to protect it from the intense summer heat and precipitation. This is the "operational cover." Waste is emplaced to within 4 feet of the surface and then is covered with an 8-foot layer of soil, resulting in a mound 4 feet higher than the natural surface. The GCD disposal units in the trenches (boreholes 1,2, and 3) were backfilled with native alluvium following waste emplacement to the bottom surface of the trench, and then subject to emplacement of LLW and the operational cover on top of that. The operational cover currently overlies the waste in the retired pits and trenches. It has served as a field laboratory for experimental planting of desert flora.

- When waste is emplaced and backfilling occurs, subsidence can occur. Measures are taken to compact the operational cover and to fill the voids between the waste containers as much as possible.

- Installation of a final closure cap, the design of which is discussed below.

- $\quad$ Final survey plot and closure certification with the State of Nevada Division of Environmental Protection.

- Post-closure monitoring, including vadose zone monitoring of moisture, soil gas, etc..

A single large enclosure cap over the entire Area 5 RWMS may be investigated as part of ongoing cap design research. However, the current design plan would result in three separate caps. Cap 1 would cover the retired pits and trenches in the center of the 92-acre LLW disposal area. Cap 2 would cover the Classified Waste Disposal Area and Pit 3 in the northeast corner of the 92-acre area. This area would include GCD boreholes 1-4. Cap 3 would be emplaced over Pit 4 and Pit 5 in the western portion of the RWMS. If constructed, each cap will be an independent and separate unit or mound.

The final closure cap(s) will meet all applicable regulations to function in the arid environment of the NTS. In general, cap design will be a monolayer-evapotranspiration cover composed of native alluvium 3 meters thick. The final design that comes out of Closure Program research will incorporate native soils and knowledge on evapotranspiration conditions prevalent at the site in order to help retard contaminant migration. 


\subsection{Long-Term Stewardship at the NTS}

A number of key long-term planning documents noted in the sidebar in the Introduction have been developed to guide decisions regarding U.S. government stewardship of the NTS and all its related missions and facilities, ultimately including the various disposal facilities (such as GCD) in the Area 3 and Area 5 RWMSs. This section briefly describes and discusses the contents of those documents.

\subsubsection{Accelerating Cleanup: Paths to Closure}

This document [DOE, 1998a] was developed by the DOE Environmental Management (EM) program office and provides a complex-wide planning document for cleaning up 53 remaining DOE facilities in the United States. It is the EM program's "blueprint" for completing cleanup of soil, groundwater, and facilities. It provides scope, cost, and schedule for over 350 projects associated with these 53 facilities. Much of the cleanup and closure activities in this report are scheduled for completion by 2006; the report also includes cost projections for long-term stewardship and maintenance (LTS\&M) through the year 2070. The Paths to Closure is based on best available "end state assumptions" provided by each site.

It is important to note that the "closure" of a site does not end DOE's responsibility. In most cases, DOE will continue long-term surveillance and monitoring activities to ensure that human health and the environment are protected. [page ES-1]

According to Paths to Closure, the total cost for cleaning up and "closing" the Nevada Test Site is projected to be over $\$ 2.1$ billion through the year 2014.

Appendix E of Paths to Closure provides brief site summaries categorized by Operations Office. Under the Nevada Operations Office summary, it is noted that the NTS is a Defense Programs site with a scheduled completion date of 2014. At the time Paths to Closure was written, it was noted that future land use, resource management, and privatization decisions would be based on and were pending release of the Resource Management Plan. Such decisions would need to include the DOE, national laboratories, the U.S. Air Force, the BLM, Tribal nations, State and local agencies, and other stakeholders.

\subsubsection{Accelerating Cleanup: Paths to Closure, Nevada Operations Office}

This document [DOE, 1998b] provides the $\mathrm{DOE} / \mathrm{EM}$ and DOE/NV plan for management, remediation, closure and long-term stewardship for the NTS and other off-site locations both from the present through 2006, and for the period " 2007 and beyond." It was published concurrent with publication of the Paths to Closure document summarized above.

A number of important provisions and assumptions are embodied in this report:

- Activities will include not only remediation and LLW and TRU waste disposal operations, but also the closure of "on-site disposal areas in compliance with regulatory requirements." (emphasis added)

- Completion of the DOE/NV Resource Management Plan was needed in order to negotiate final cleanup levels.

- Renegotiation of the FFACO(Federal Facility Agreement and Consent Order) will not be required.

- Waste Management (WM) projects are defined (limited) by the current NTS EIS Record of Decision (ROD). It was anticipated that completion of the WM Programmatic EIS (PEIS) could change current assumptions and planned actions for WM projects.

- LLW disposal operations will continue through the year 2070.

- "Institutional control of the NTS is assumed in perpetuity at the existing boundaries." (emphasis added). If DOE ceases to exist, it is assumed that "another federal agency will become the landlord.....as institutional control of the site is considered an obligation of the federal government and one that is expected to be maintained." 
- "DOE will maintain a presence at the NTS to ensure reduced risks to human health and the environment. This long-term stewardship will include passive and active institutional controls, the degree of which will be determined through negotiations between DOE/NV, regulators, Tribal Nations, and stakeholders." (emphasis added)

- Underground nuclear tests will not be remediated due to lack of cost-effective groundwater treatment technologies.

- Surface soil plumes will be characterized, remediated, and monitored.

- "The nature and extent of contaminated sites must be adequately understood to avoid developing overly prescriptive long-term surveillance and monitoring requirements based on worse case scenarios.... Subsurface monitoring will take place for two to three years then responsibility will transfer to the U.S. Environmental Protection Agency (EPA) for long-term monitoring. Subsurface monitoring is planned for 100 years because of the nature and extent of subsurface contamination."

The definition of the "EM end state" for NTS is as follows:

Future land use decisions for the Nevada Test Site will be compatible with the Resource Management Plan... The NTS (Defense Programs) mission is to maintain a primary site for Operational Readiness and Stockpile Stewardship. Contamination from past nuclear testing as well as waste disposal areas necessitate institutional control of the existing boundaries of the NTS for the foreseeable future. (emphasis added) Filled disposal pits and trenches will be closed and capped as appropriate. To support landlord operations (Defense Programs), storage and disposal operations may continue at the former waste management locations.

Future use of the site is "uncertain at this time" due to ongoing planning discussions with the many current and potential government and private agencies and parties involved. "The DOE is assumed to retain oversight and management of the NTS for the foreseeable future. (emphasis added) Long-term monitoring of the site is assumed..." (the latter was calculated for 100 years for costing and planning purposes.).

For the TRU/Mixed TRU waste areas, including the GCD boreholes, the projected end state is that the "facility will be turned over for alternate use by low level waste program in FY 2004. Long term surveillance and monitoring will be conducted, as required, as part of the long-term monitoring program for the RWMS under LLW for TRU formerly disposed of in GCD holes in Area 5 RWMS."

For the LLW program, status by 2006 and beyond is "ongoing based on the need for continued radioactive waste disposal capabilities at the NTS.... for now, acceptance of LLW is assumed to FY 2070." Site monitoring will ensure the performance objectives of the site continue to be met. A PA maintenance program will provide for out-year updates and verification of the site data. It is stated that post-2006, performance assessments will be updated as long as waste disposal continues. The end state for LLW is: "As disposal units are filled, closure will be conducted. Long-term surveillance and monitoring is planned for 2071 through 2100. All legacy and disposalrelated activities will have been completed."

\subsubsection{NTS Resource Management Plan}

This document [DOE, 1998c] describes the NTS Stewardship Mission and how accomplishing it will preserve the resources of the ecoregion while accomplishing the objectives of the Mission. There are defined goals for 12 resource areas, including:

- $\quad$ Mission (for underground testing)

- $\quad$ Site support activities and facilities

- Health and safety

- Land use and impacts

- Water

- Cultural

- American Indian

- Biological 
- Air

- Geological and mineral

- Airspace

- Socioeconomic

The Resource Management Plan provides both overall and resource-area specific guidance on the status of the given resource area, data requirements and management, monitoring provisions, and "adaptive management." This document references the Accelerating Cleanup: Paths to Closure plans and documents for the Environmental Restoration and Waste Management functions and activities and their integration. The planning horizon is still noted for FY 2006 and includes remediation activities, closure of disposal areas in compliance with regulatory requirements, monitoring to ensure performance objectives are met, and maintaining a presence at the NTS including passive and active institutional controls.

Section 10 of the Resource Management Plan provides a summary of current and projected uses and zoning for the NTS to support its various missions. It also provides a good summary of the legal and policy provisions established for the NTS in the Public Land Orders and the laws that govern the existing land withdrawals. There is uncertainty regarding the potential impact of proposed NTS activities (spelled out, for instance, in the EIS) on the status of the land withdrawals. DOE and the U.S. Department of Interior (DOI) are involved in ongoing discussions to understand and resolve these uncertainties.

Section 11 of the Resource Management Plan deals with maintaining the supply and quality of water resources needed to support all of the missions and the present/future users of water at the NTS. Presently, water use on the NTS has little or no effect on the migration or spread of contamination from historical underground nuclear testing. Much of that contamination is localized near the test cavities. DOE maintains sovereign immunity from state water management where the water is used for the purposes for which the land was withdrawn. At present, NTS water use has not had impacts on down-gradient water rights holders, but this is an ongoing assessment process. This section also summarizes the extensive ongoing monitoring program for both groundwater and surface waters. The Routine Radiological Environmental Monitoring Plan is referenced. This section also discusses the importance of the National Environmental Policy Act (NEPA) process in water resource planning; the Groundwater Protection Management Program Plan; the Test Readiness Program (as it relates to the impacts on groundwater protection); and the Underground Test Area Project (to evaluate the nature and extent of contamination and the need for and implementation of remedial actions).

\subsubsection{From Cleanup to Stewardship}

This is a companion document to Paths to Closure and provides background information for a scoping process under NEPA on long-term stewardship activities [DOE, 1999b]. One of the key questions this document seeks to answer is "How do we ensure effective long-term stewardship of sites with residual waste and contamination?" As noted, "long-term stewardship includes all activities required to protect human health and the environment from hazards remaining at DOE sites after cleanup is complete." It is noted that "overall requirements for stewardship over these sites and hazards are prescribed by statute, and additional requirements to implement these requirements are contained in regulations and DOE directives." In other words, stewardship requirements for the GCD boreholes are contained in DOE Order 5820.2A and 40 CFR 191.

\subsubsection{General Provisions}

From Cleanup to Stewardship defines two general categories of stewardship activities: 1) active controls, and 2) passive controls (see page 15 for examples given in these definitions). The local decision-making process during cleanup (for instance, NTS closure, cleanup, and maintenance) will spell out decisions about the required stewardship activities. This document specifically used as an example the requirements from 40 CFR 191 in defining "institutional controls." Even though this regulation limits the credit that can be taken for active controls (e.g., 100 years for modeling), it also requires maintenance of controls 
for as long a period as practicable. As such, it is concluded that DOE is generally required to implement controls at waste disposal sites for the foreseeable future. This is a key element to ensure land use restrictions are maintained. Therefore, "successful implementation of these institutional controls will require coordination between Federal agencies as well as Tribal, state, and local governments."

Other agencies are also required to implement such controls; for instance, EPA has developed Guidance on the use and implementation of institutional controls. It is noted, however, that "the specific ways in which long-term institutional control issues are implemented vary considerably at state and local levels." The Department of Defense will be publishing guidance on long-term care issues in The Road to Site Closure in the spring of 2000. NRC has also published regulations that address long-term stewardship for NRC-licensed decontamination \& decommissioning (D\&D) sites where unrestricted use is not attainable.

Of 109 sites across the nation, DOE expects active stewardship at 103 and sole reliance on passive controls at only 6 sites. Stewardship is categorized by 4 media types:

- Water, which includes groundwater, surface water, and sediments. (100 sites)

- Soil, which includes release sites, burn pits, burial grounds, and areas contaminated from underground utilities, tanks, and surrounding buildings. (71 sites)

- Engineered Units, (as in GCD disposal) which include radioactive, hazardous and sanitary landfills; vaults; and tank farms with man-made containment systems. These may require active measures like leachate collection, cap maintenance, erosion control, and access restriction. (70 sites)

- Facilities, which include entombed reactors, canyons and other buildings with residual contamination, as well as remaining infrastructure. (32 sites)

Future land use, cleanup strategies, and long-term stewardship provisions are interdependent. Land use categories are being defined (e.g., industrial vs. recreational, for instance). For many sites, "active DOE control of the site is expected to continue indefinitely." For instance, one of the primary missions of the Grand Junction Office is to assume long-term custody of certain sites where cleanup is complete. $\mathrm{DOE} / \mathrm{NV}$ is responsible for long-term stewardship at former sites the United States conducted nuclear tests (the Nevada "offsites"). DOE is seeking to lower the post-cleanup risks as much as possible and, as a result, the required costs for long-term stewardship site maintenance. Those long-term funding requirements are not well defined. DOE/NV has managed long-term stewardship (mostly water sampling near test locations) for 25-35 years at a cost of about $\$ 30 \mathrm{k}$ to $\$ 50 \mathrm{k}$ per site. "These activities are assumed to continue indefinitely."

With respect to planning for long-term stewardship,

The uncertainties associated with longterm stewardship of DOE sites include the nature of the hazards, the effectiveness of monitoring and maintenance of barriers and institutional controls, and the cost of these activities. Other unknowns include the availability of adequate technologies, the future development of better remedial and surveillance technologies, long-term funding and other resources, and longterm management of data.

Another concern lies with the long-term management and control of "materials in inventory" at some DOE sites through stabilization and long-term storage.

\subsubsection{NTS - Specific Provisions}

Appendix E of From Cleanup to Stewardship provides site profiles. The summary for the NTS is brief. It states that the federal government will own the land for the foreseeable future and that "...future land use decisions for the NTS will be compatible with the Resource Management Plan," and will involve all the various agencies and stakeholders. "Most of the site will be used to 
support ongoing Defense Program operations and will remain under controlled access....Subsurface contamination will remain in place in both on and offsite areas where underground testing was conducted. These areas will be monitored and institutional controls will be maintained by DOE to prohibit access to soil and groundwater contamination in these areas." Institutional control will continue for the foreseeable future due to the nature and extent of remaining contamination and the potential future need for nuclear testing. Using the Resource Management Plan, DOE/NV will negotiate final cleanup levels with state regulators based on future land use decisions. Total longterm stewardship and maintenance costs through 2070 could amount to almost $\$ 5$ million per year.

For soil, "corrective action of NTS's soil sites will be conducted in areas designated for alternative future uses. Filled disposal pits and trenches will also be closed and capped to the extent possible... Plans are currently being developed for a monitoring network, program, and schedule acceptable to DOE, the State of Nevada, and stakeholders..." but monitoring is expected to last for the foreseeable future.

For water, tritium is the main indicator and natural attenuation will be the primary remediation strategy for contaminated groundwater. Restrictions will remain in place to prevent access to these waters and "...the site will monitor groundwater for at least 100 years in areas where significant potential for migration of contaminants exists." For engineered units, "disposal areas will be monitored and routine maintenance conducted to control erosion and maintain flood control capabilities in these areas."

\subsubsection{When is Stewardship Needed?}

Appendix C of From Cleanup to Stewardship discusses the methodology to be used in achieving closure for many facilities. Under the heading of "Site End State," a significant statement is made:
Remediation to levels acceptable for unrestricted use is not considered to require stewardship because this level of use is based on calculations that project that unacceptable human health risks will not occur even under the most extensive exposure scenarios (e.g. residential use).

Taken literally, this says that if the PA for the GCD facility shows compliance (as was demonstrated in Volume 2 of this CAD) when all uncertainties for all significant processes and events and (where applicable) exposure scenarios are considered, then the need for application of long-term stewardship, monitoring, and other Assurance Requirements could be questioned. However, given the requirement to "comply with regulatory requirements," governing requirements in 40 CFR 191 for Assurance provisions must be met. Also, it is noted on the same page of Appendix C of From Cleanup to Stewardship for the category of Engineered Units (which includes facilities like the GCD boreholes),

All engineered units that are likely to remain onsite are assumed to require some type of long-term stewardship, partially as a result of the post-closure care activities required in the various regulations [such as 40 CFR 191] that apply to DOE's waste disposal activities, but also due to the general nature of the units. Engineered units are areas where wastes and residual contamination are consolidated for permanent disposal or long-term retrievable storage. Therefore, these units will require stewardship activities.

Therefore, it is clear that some program of longterm stewardship, monitoring and control (e.g. assurance) must be implemented. That is the subject of Section 4. 


\subsection{Application of Assurance Requirements at the GCD Site}

This section presents the specific actions DOE will take to comply with the Assurance Requirements of 40 CFR 191. The specific commitments DOE will make are commensurate with the risk associated with the TRU wastes disposed in GCD boreholes. The following subsections summarize the 40 CFR 191 Assurance Requirements (already discussed in detail in Section 1), and then present specific DOE actions for meeting the Assurance Requirements.

Where applicable, each subsection provides a summary of subject matter expert (SME) observations regarding Assurance Requirements. The SME views and opinions were expressed as part of an expert elicitation conducted during the summer of 1996 for the Area 3 and Area 5 RWMSs [Black et al., 2000]. Whereas, the SMEs views or opinions might have changed since that time (because of changes in society and technology, or, in general, because their relevant knowledge base might have changed), the information obtained from the SMEs is expected to continue to have value considering the relatively short time since the elicitation was performed. The elicitation was focused on obtaining information that would permit probabilistic assessment of the potential for inadvertent human intrusion (IHI) into intermediate depth buried waste at the Nevada Test Site. The expert elicitation dealt with a number of possible site-specific human intrusion scenarios (both homestead and three community scenarios), coupled with suitable management controls of the site. The management control features included institutional control, site knowledge (records), placards and markers, surface barriers, and subsurface barriers. These factors, together or independently, would prevent IHI while they were actively maintained and remained effective. The effectiveness of the management controls were combined with evaluations of the conditional probabilities of IHI for the scenarios. The results and insights obtained are directly relevant to the GCD CAD because, specifically, they pertain to the Area 5 RWMS.

The SMEs raised the issue of periodic review of the results of the elicitation. Their reasoning was based on concerns that societal and technological advances were possible that could change the conditions, or relevant knowledge base, for the elicitation. The SMEs' concerns regarding periodic review were in line with those of the stakeholders who attended a stakeholder workshop for this project prior to the elicitation (see Black, et al., 2000). The concept of periodic review is also consistent with the concepts of performance assessment maintenance programs required by DOE Order 5820.2A. The SMEs suggested that some form of financial trust or periodic review mechanism would have to be established to ensure that periodic review would occur. The SMEs also noted a further benefit of periodic review; that, while periodic review capabilities are maintained, the likelihood of continued institutional control is increased. The SMEs also discussed what they considered to be reasonable time frames for periodic review. Two cases were considered. The first was regular periodic review on a generational basis (e.g., 25 years) both to re-perform the evaluation, and to ensure transfer of knowledge across generations. The second involved recognition that drastic changes to society (e.g., population changes) or technology could have a substantial effect on the results of the elicitation, and, hence, should require an earlier review. The two cases together require some form of institutional watch-body to evaluate if societal or technological practices have changed sufficiently that an earlier review is warranted. The link between institutional control and periodic review was seen as mutually beneficial to both concepts, while political will and funding was seen as fundamental to the success of such a program.

In order to fully comply with 40 CFR 191 Assurance Requirements, DOE will need to ensure long-term financial commitments are established in separate financial planning documents. The need for financial assurance is particularly important to establish and maintain active and passive institutional controls and monitoring.

\subsection{Site Selection and Resources}

\subsubsection{Requirements and Discussion}

40 CFR 191.14(e) states (in part) the following: 
Places where there has been mining for resources, or where there is a reasonable expectation of exploration for scarce or easily accessible resources, or where there is a significant concentration of any material that is not widely available from other sources, should be avoided in selecting disposal sites...Such places shall not be used for disposal of the wastes covered by this part unless the favorable characteristics of such places compensate for their greater likelihood of being disturbed in the future. (emphasis added)

The EPA, in its Standard, is searching for the best overall protection afforded by the site and the disposal concept for the site. While siting should identify and screen those sites that have significant resource potential, it should also not necessarily preclude favorable sites if it can be shown that the positive and superior characteristics of the site might outweigh the detriments from exploratory activities. The regulations provide the flexibility for DOE to demonstrate satisfactory performance of the site in the PA through inclusion of appropriate human intrusion scenarios, and use that analysis as justification for meeting this Assurance Requirement.

\section{Key Concepts for Site Selection}

$\mathrm{T}$ disincentive to site near resources

$\mathrm{T}$ preference given to such sites

$\mathrm{T}$ however, sites in areas of significant resource potential are not precluded...

$\mathrm{T}$ favorable characteristics must outweigh the detriments from exploration

\subsubsection{SME Observations}

In the early stages of the elicitation session, the SMEs developed scenarios by which human settlement might occur in Frenchman Flat. Natural and accessible resources were considered as part of this development. The SMEs included experts in agronomy, economic geology and natural resource use, as well as people who had local knowledge of the resource requirements of the area. Topics discussed included subsurface resources such as water, oil, gas and minerals; gravel; and surface resources needed to provide suitable conditions to support farming or ranching.

The SMEs agreed that none of the natural or accessible resources available at Frenchman Flat could be utilized in an economically viable way. They indicated that the expense of obtaining sufficient water to support farming was prohibitive; and that ranching was not viable in the northern Mojave desert in which the RWMS is located. The need for gravel was suggested to be limited given the distance from Las Vegas and other population centers, and the comparatively weak demand for gravel compared with its availability. The SMEs also discussed the viability of mining salt from the playa that drains Frenchman Flat, but dismissed the option and went on to suggest that the playa should not be considered further as a possible location for human settlement. The SMEs also dismissed oil and gas as available resources because they do not exist in significant quantities at Frenchman Flat. They recognized that minerals, in particular, some metals, exist in small concentrations in the alluvium of Frenchman Flat, but that the quantities are so small that, with current technology, it is not economically viable to mine them.

Overall, most resources were considered too sparse for further evaluation and were dismissed as potential contributors to settlement of Frenchman Flat. The only resource considered further was water because of its abundance, and the potential for developing a well system that might support a small community or individual homesteaders.

\subsubsection{DOE Actions}

The GCD borehole sites were selected and put into operation prior to promulgation of the 1985 version of 40 CFR 191. The site selection process took into consideration, among numerous factors, the proximity to and possibility of exploratory activities for resources. The only significant resource at the NTS and specifically in the location of the Area 5 RWMS is water. No other significant minerals or resources of value would be of interest to current or future residents of the site, 
assuming the site were released for unrestricted use. See the detailed discussion of resources in subsection 4.5.3 below.

The upper aquifer underlying the Area 5 RWMS is suitable as a source of drinking water except for the presence of dissolved manganese. Though the water table is deep (about $240 \mathrm{~m}$ ), this depth does not preclude potential drilling for water for domestic purposes and irrigation in the future. However, current and anticipated future provisions for site restrictions and control would prevent such drilling activity. In addition, despite the proximity of suitable water, the extremely arid nature of and overall condition of the soils in this area are generally not conducive to human activities (such as irrigated farming, ranching, etc.) that would require significant quantities of water supplied locally.

The GCD site has been shown to have favorable characteristics that support its use as a superior disposal concept for TRU wastes. Therefore, DOE concludes that the favorable characteristics of the site more than compensate for the very low likelihood of future disturbance of the waste due to human activities that might involve drilling for water.

\subsection{Future Waste Removal}

\subsubsection{Requirements and Discussion}

40 CFR 191.14(f) states the following:

Disposal systems shall be selected so that removal of most of the wastes is not precluded for a reasonable period of time after disposal.

The DOE will need to demonstrate that, given the design features and methods for waste disposal in the GCD facility, future removal of wastes is technically feasible, however difficult or expensive. Technical feasibility is based on technology levels at the time of disposal, without the need for additional procedures or design features to accommodate the removal of wastes.

\section{Key Concepts for Waste Removal}

$\mathrm{T}$ recovery need not be easy or inexpensive, but only possible

$\mathrm{T}$ no additional procedures or design features

$\mathrm{T}$ must only be technologically feasible

$\mathrm{T}$ future generations must have this option

\subsubsection{DOE Actions}

The GCD boreholes 1-4 were sited and designed, augered to depth, filled, and backfilled in a manner that does not preclude exhumation of the emplaced wastes in the future. The augering technology that was used to "mine" these boreholes in the first place is simple in concept and does not require any new developments or procedures for adaptation to waste removal. As such, DOE concludes there is no need for extensive plans or efforts to demonstrate the technical feasibility of future waste removal from the GCD boreholes.

This conclusion is consistent with the preamble discussion by EPA in 40 CFR 191 that:

...any current concept for a mined geologic repository meets this requirement without any additional features or design procedures....it only need be technologically feasible (assuming current technology levels) to be able to mine the sealed repository and recover the waste... [50 FR 38082]

Any future plans for waste removal would be relatively simple in scope and would include considerations for minimizing contamination and human exposure, cap removal, monitoring during removal operations, interim storage of backfill and contaminated backfill, equipment requirements and remote removal operations, handling and packaging, surveying, on-site storage of wastes, decontamination, and transportation to future alternative waste handling facilities. After waste removal, the GCD boreholes would be decontaminated, backfilled, and decommissioned in accordance with applicable regulations. 


\subsection{Barriers and Defense in Depth}

\subsubsection{Requirements and Discussion}

40 CFR 191.14(d) states the following:

Disposal systems shall use different types of barriers to isolate the wastes from the accessible environment. Both engineered and natural barriers shall be included.

To adequately address the intent of 40 CFR 191.14(d), DOE provides (in the CAD PA analysis) a description and analysis of the natural and engineered barriers that will be used for the GCD disposal facilities. Similar to the WIPP certification requirements [EPA, 1996] noted in the Appendix, the regulations in 40 CFR 191 do not mandate specific barrier types or the implementation of more than one engineered barrier. The emphasis in the regulations and guidance promulgated by EPA is on the "best performance reasonably achievable." DOE Order 5820.2A defines engineered barriers as "a man-made structure or device that is intended to improve the performance of a disposal facility."

\section{Key Concepts for Barriers}

$T$ both engineered and natural barriers

$\mathrm{T}$ barriers to waste isolation

$\mathrm{T}$ "defense in depth"

$\mathrm{T}$ "best performance reasonably achievable"

\subsubsection{SME Observations}

The SMEs considered both subsurface and surface barriers for their potential to deter IHI. Note that, as opposed to barriers to waste isolation, the SME analysis was confined to barriers to human intrusion, called "protective barriers," which are not required by the regulation. Where subsurface barriers were concerned, the SMEs, who included several people with well-drilling experience and expertise, felt that most water-well drilling efforts would not be impeded by subsurface barriers. They were careful to distinguish between water- well drilling and exploratory drilling for resources. The SMEs indicated that, for most water-well drillers, the relative cost of re-siting a drill rig was greater than replacing broken drill bits, and that most subsurface barriers would not be successful deterrents. They also indicated that most waterwell drillers would not notice or recognize radioactive waste that might be brought to the surface, because, in general, their focus is reaching the water table, and not evaluating cuttings for their composition. In contrast, the SMEs recognized that when drilling for exploratory purposes it is reasonable to expect that the cuttings would be evaluated and, hence, radioactive materials in the cuttings would be recognized.

Specific suggestions made by the SMEs for subsurface barriers that might effectively impede water-well drilling included: concrete reinforced with rebar at six inch intervals and several feet thick; wire mesh tens of feet thick; or, rubber tires tens of feet thick. However, the SMEs also recognized that a titanium cone-shaped shield placed over the GCD boreholes would effectively re-direct a drill away from the GCD boreholes. They recognized that such a cover could only be used if the waste footprint was small, like those of the GCD boreholes. The SMEs also considered layers of colored sand as a warning sign, but countered, again, with the argument that water-well drillers would not be easily dissuaded from drilling.

The SMEs thought that surface barriers could be designed that would more easily deter water-well drillers. They focused on deterring a water-well driller from siting a drill rig over the disposed waste. The SMEs indicated that a steep slope coupled with large boulders over the entire waste footprint would persuade well drillers to move to a different location. They suggested that an immediate slope of at least two to one would be needed to prevent drill rigs from mounting the barrier, and that at least a 10-foot high mound of very large boulders would be necessary to deter siting a drill rig. Issues raised by the SMEs that might constrain the ability of the barrier to endure included subsidence of the disposalcells, natural erosion, stability of the barrier slope, and durability 
of the materials used. However, the SMEs thought that their preliminary designs, including slope and boulders, would be sufficient for the surface barrier to endure for 10,000 years. Also, the SMEs thought that this type of surface design could be constructed to accommodate the subsidence potential of the LLW disposal cells.

The only concern raised by the SMEs that was not accounted for by their preliminary designs, was that the very visual nature of the surface barrier could attract curious investigators and, hence, promote advertent intrusion. The SMEs recognized that this was not part of the scope of the project or the regulations, but, nevertheless, suggested that this scenario probably has greater potential in such a hostile environment than does inadvertent human intrusion because of human settlement and associated water-well drilling. The SMEs suggested that the best way to deter advertent intruders was to return the site surface to its natural condition.

The SMEs focused on "protective barriers" as the best method to deter well drilling and to prevent IHI into the disposal facilities. As the SMEs noted however, surface barriers, monuments, markers and the like might attract attention. In addition, the EPA regulations are primarily concerned with barriers for waste isolation and not protection of, or preventing disturbance of disposal facilities by, human intruders.

\subsubsection{DOE Actions}

In general, disposal system PA may model and analyze the natural and engineered barriers to migration of waste. GCD disposal system barriers include the chemical and physical barriers in the vicinity of the waste (e.g., oxidizing steel containers) resulting in sorption of radionuclides; the use of probertite for criticality control in the borehole fill; $21 \mathrm{~m}(70 \mathrm{ft})$ of backfill; the native alluvium and the extremely dry conditions of the soils and vadose zone surrounding the waste; and the engineered cap anticipated for the boreholes and the trenches they are located in.

The GCD PA took limited credit for these barriers and focused on modeling the undisturbed condition of the natural setting (e.g. the arid alluvium) and the very slow movement of moisture. However, the PA assumed oxidizing conditions and radionuclide sorption. The results of the PA demonstrated compliance with the CRs of 40 CFR 191; therefore, the natural barriers at the GCD facility provide effective isolation of wastes from the accessible environment and humans. As such, DOE has determined that there are no further analyses required to demonstrate compliance with the intent of this Assurance Requirement.

However, DOE/NV intends to include engineered barriers in the final assessments and closure plan [Bechtel Nevada, 2000] for the GCD boreholes. $\mathrm{DOE} / \mathrm{NV}$ intends to establish appropriate engineered barriers at a later date but will ensure that it meets the requirements of 40 CFR 191 prior to the final closure of the Area 5 RWMS facilities.

\subsection{Monitoring}

\subsubsection{Requirements and Discussion}

40 CFR 191.14(b) states the following:

Disposal systems shall be monitored after disposal to detect substantial and detrimental deviations from expected performance. This monitoring shall be done with techniques that do not jeopardize the isolation of the wastes and shall be conducted until there are no significant concerns to be addressed by further monitoring.

The provisions for monitoring will follow the same set of general guidelines as was specified for WIPP [EPA, 1996] as noted in the Appendix. That is, monitoring must not jeopardize the isolation capabilities of the disposal system. DOE will need to monitor those parameters that are important for demonstrating the system is behaving and performing as intended. The monitoring program should provide meaningful data in a relatively short period of time, and should continue until there are no significant concerns or indications of "detrimental deviations" from expected performance. The monitoring program should be designed to gather baseline data during the pre- 
closure period, followed by a reasonable period of monitoring during the post-closure phase.

\section{Key Concepts for Monitoring}

$\mathrm{T}$ address significant parameters and concerns (consistent with the PA)

$\mathrm{T}$ detect substantial and detrimental deviations from expected performance

$\mathrm{T}$ preserve system integrity

$\mathrm{T}$ obtain meaningful data in a short period of time

$\mathrm{T}$ integrate with other monitoring programs (RCRA, LLW, NTS-wide)

$T$ not a reason to relax the rigor used in the PA analysis

\subsubsection{DOE Actions}

DOE currently has a monitoring plan for the NTS, including the Area 5 RWMS pits and trenches [Bechtel Nevada, 2000]. The objectives of this program are to characterize the hydrologic properties of the uppermost aquifer and the lithologic and stratigraphic conditions, and to measure background concentrations of radionuclides and RCRA constituents. The monitoring plan for post-closure for the GCD boreholes will be incorporated into and integrated with the existing monitoring provisions for the LLW trenches.

| The final design of the monitoring provisions | applicable to GCD borehole performance, to I ensure compliance with the Assurance Requirements, should be based on the results of the GCD PA (documented in the CAD Volume 2). The important parameters that will drive the design of the monitoring program are defined by the PA. Table 4-1 summarizes monitoring requirements to verify expected performance of the GCD TRU waste disposal site at the Area 5 RWMS. These requirements are included in the Integrated Closure and Monitoring Plan [Bechtel Nevada, 2000]. However, the details of the monitoring program and the timing of its implementation cannot be specified at this time due to a number of factors:

- waste operations may continue in the immediate vicinity of the GCD boreholes for a number of decades;

- the site-wide integrated monitoring and closure plans are now in place but may be revised as operations continue. These plans include GCD monitoring requirements and provisions;

- $\quad$ the GCD PA (as well as other NTS PAs) will undergo periodic review under the site-wide maintenance plans that are being developed; as such, new knowledge may lead to revisions to key parameters and indicators and associated monitoring recommendations.

Because of these constraints, it is not possible at this time to establish monitoring durations, specific parameters and measurement locations or methods, or the "trigger or action levels" that indicate "substantial and detrimental deviations from expected performance." These monitoring plan design details will be developed when information is available and will be incorporated in separate DOE documents in the future.

Ultimately, if the monitoring plan, implementation, and results are satisfactory to the State of Nevada, then a closure report will be prepared and submitted to the Nevada Division Environmental Protection for approval. Post closure monitoring will be consistent with the requirements of compliance. Long-term monitoring of the NTS is assumed for the foreseeable future due to the nature of contaminants remaining in the subsurface as the result of historical nuclear testing activities.

The following are the general provisions DOE will include in its post-closure monitoring program design for the GCD boreholes, based on Table 4-1: 
Assurance Requirements at the GCD Site

\begin{tabular}{|c|c|c|c|c|c|c|c|}
\hline & 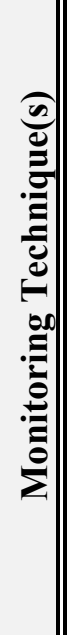 & 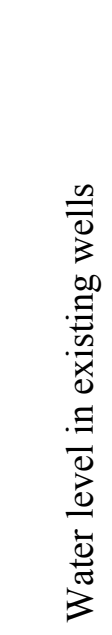 & 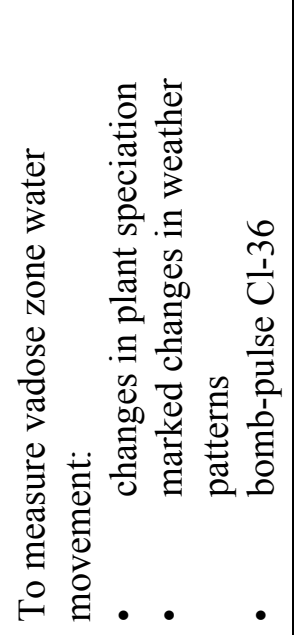 & 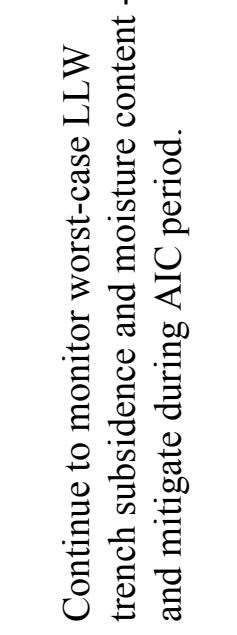 & 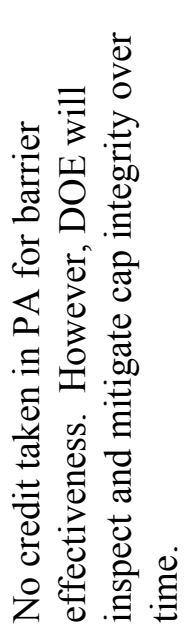 & 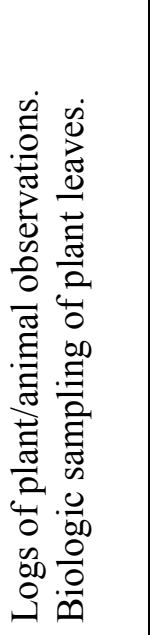 & 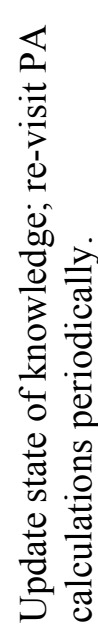 \\
\hline 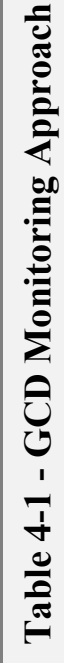 & 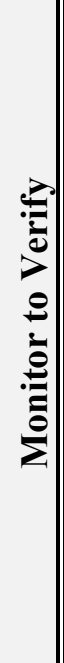 & 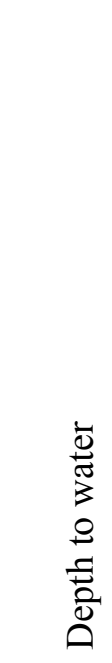 & 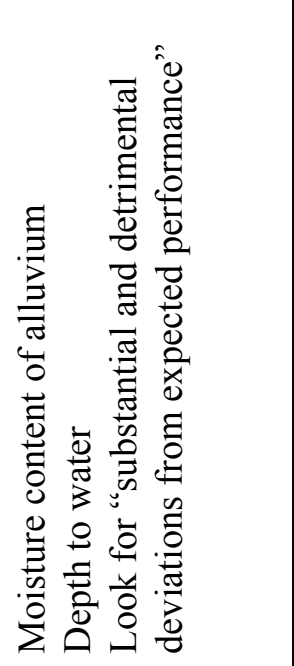 & 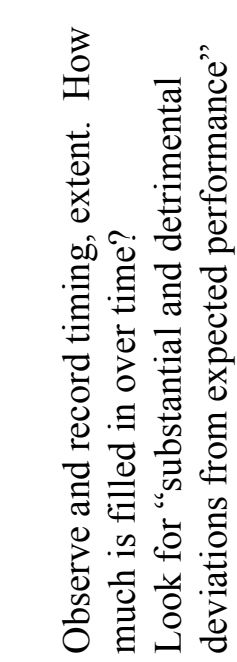 & 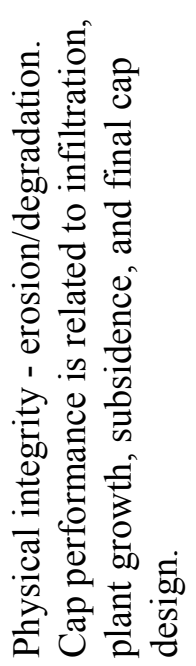 & 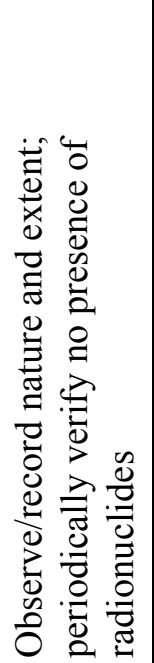 & 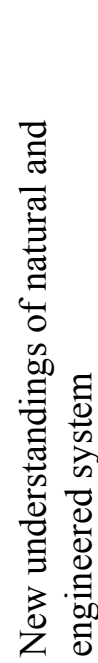 \\
\hline & 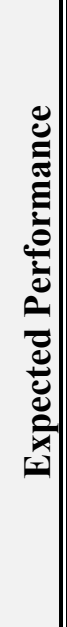 & 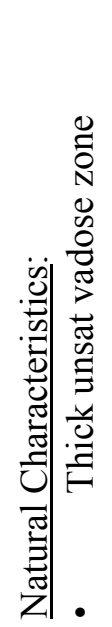 & 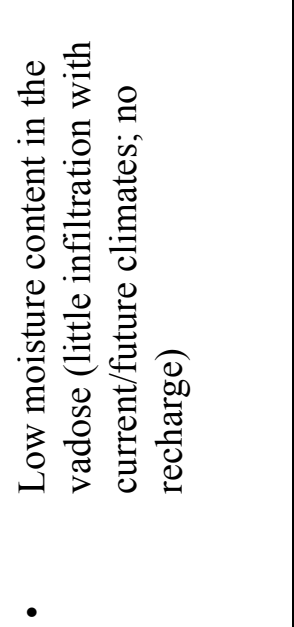 & 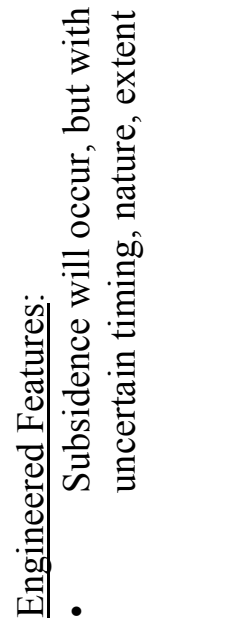 & 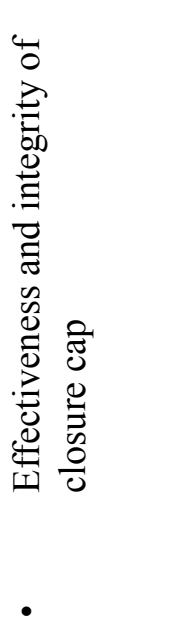 & 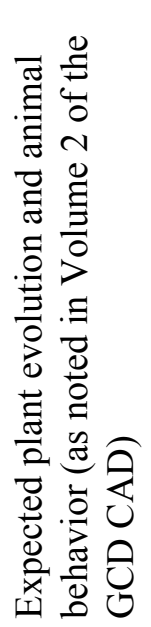 & 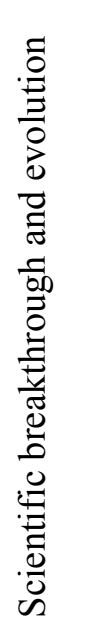 \\
\hline
\end{tabular}


1. The natural system and its characteristics will be monitored and measured to verify expected performance and changes over time. Of particular concern is verification that the very low moisture contents and slow movement of moisture in the thick vadose zone continue into the foreseeable future as modeled in the PA. This monitoring will include depth to water measurements and various methods to measure moisture content in the alluvium.

This monitoring will note significant changes in infiltration, recharge (if it occurs), and moisture contents and the effects those changes have on assumptions regarding upward advective flux in the PA.

The EPA noted in their preamble discussion to $40 \mathrm{CFR} 191$ that "monitoring for radionuclide releases to the accessible environment is not likely to be productive." Therefore, there is no requirement for nor need to include detection of radionuclides in the plan for GCD monitoring.

2. The actual nature and extent of plant and animal bioturbation will be measured, observed, and monitored to verify assumptions made in the PA on its effect over time. Appropriate methods to prevent or minimize the effects of bioturbation will be analyzed and implemented where appropriate.

3. Closure cap performance monitoring will verify the integrity of the cap against design criteria for a reasonable period of time following closure. Since final closure cap design has not yet been established, the specific requirements and key indicators for cap monitoring cannot be established at this time.

4. The nature, extent and timing of subsidence and its impact on performance will be measured and monitored. Measures that are taken to mitigate any observed subsidence will be documented and used to update the models and results of the PA if necessary.

5. As noted, the GCD PA and monitoring data will undergo periodic review as determined by DOE long-term stewardship and maintenance schedules. As new knowledge is gained (perhaps through scientific breakthroughs) about the system, the state of knowledge will be updated and PA calculations re-visited, consistent with the methodology used for the original PA.

\subsection{Active Institutional Controls}

\subsubsection{Requirements and Discussion}

40 CFR 191.14(a) states the following:

Active institutional controls over disposal sites should be maintained for as long a period of time as is practicable after disposal; however, performance assessments that assess isolation of the wastes from the accessible environment shall not consider any contributions from active institutional controls for more than 100 years after disposal.

To meet the Assurance Requirements, DOE will need to plan for implementation of AICs for as long as "practicable," (specific credit for such controls in the PA cannot be taken for more than 100 years following disposal and closure of the facility). Such controls will act to prevent unauthorized uses of the GCD site.

\section{Key Concepts for Active Controls}

$\mathrm{T}$ implemented for as long as practicable

$\mathrm{T}$ control of the NTS by DOE is assumed "indefinitely" and for the "foreseeable future."

$\mathrm{T}$ describe the controls; to include access control, routine maintenance and remedial actions, controlling releases, or monitoring

$\mathrm{T}$ support assumptions regarding effectiveness

$\mathrm{T}$ only credit for 100 years in the PA 


\subsubsection{SME Observations}

One of the assumptions of the expert elicitation was that IHI could not occur if institutional control was in effect. Consequently, the SMEs discussed institutional control from the perspective of scenarios by which institutional control might evolve and ultimately cease, and the time frame in which that might happen. The SMEs specific expertise in anthropology and sociology provided the relevant knowledge to address the effectiveness of past civilizations to similarly control important property. The SMEs' inputs were based on their knowledge of past civilizations and their belief that the U.S. Government is stable, that it has been stable for a considerable period of time, and that it shows no obvious signs of destabilizing at this time. They compared the current U.S. society with past civilizations such as the Chinese dynasties and the British Empire, as well as religious institutions such as Christianity and Judaism.

The SMEs initially focused on different forms of institutional control that might occur. They discussed three mechanisms through which institutional control might be lost. The first was erosion of control, or a gradual decline in perception of the importance of the site. For example, the SMEs opined that the federal government could be expected to pass institutional control to the State of Nevada, who in turn might ultimately pass control to the counties or to private industry, given sufficient time. The SMEs regarded the LLW sites as relatively unimportant compared with, for example, the Yucca Mountain high-level waste repository should it become operational. Their perceived lack of importance of the LLW sites, coupled with the SMEs' historical knowledge of past civilizations led the SMEs to suggest that this was the most likely form by which institutional control would be lost. The second method suggested by the SMEs by which institutional control might be lost was political instability such that control might be relinquished during political upheaval or for economic reasons as political priorities change. The final reason offered by the SMEs was catastrophic loss of control, either naturally (e.g., earthquakes, meteors) or anthropologically (e.g., war). The SMEs rejected this as a viable option for further consideration because they considered this to be very unlikely compared with the other alternatives.

The SMEs unanimously agreed that institutional control would not last for 10,000 years (which was used in the elicitation as a target compliance period) because no human institution, government or political civilization, has lasted for this length of time. Instead the SMEs focused on the time frame in which institutional control might be lost. As summarized in Table 4-2, the SMEs suggested that it was very likely that institutional control would be lost within 1,000 years ( $90 \%$ probability), that institutional control has a reasonable chance of lasting about 250 years ( $50 \%$ chance) and that it was very likely to last at least 50 years $(90 \%$ chance). The SMEs also suggested that 2,000 years is the longest period of time for which institutional control could reasonably be expected to last. The SMEs considered a time frame of 100500 years for institutional control given their expectations that it would take this long for sociopolitical will to erode sufficiently for institutional control to cease.

Table 4-2 - Expert Elicitation Estimates of Durability of Active Institutional Control

\begin{tabular}{|c|c|}
\hline $\begin{array}{c}\text { Number of Years of } \\
\text { Active Controls }\end{array}$ & $\begin{array}{c}\text { Probability That } \\
\text { AIC Will Be Lost }\end{array}$ \\
\hline \hline 50 & 0.1 \\
\hline 250 & 0.5 \\
\hline 1000 & 0.9 \\
\hline
\end{tabular}

\subsubsection{DOE Actions}

The program for active institutional controls for the Area 5 RWMS and the GCD boreholes will be consistent, where appropriate, with the provisions in place or anticipated for the entire NTS and surrounding Federal lands [DOE 1996a, DOE 1998 b, DOE 1998c] as noted in the referenced documents and subsections 2.1 and 3.2. The DOE program for AICs will include the following:

1. As noted in subsection 2.1, DOE has entered into agreements and ongoing discussions with the NTTR, BLM, the Fish and Wildlife 
Service, and the State of Nevada regarding long-term ownership and control of the lands including and surrounding the NTS. Where agreements with these agencies are not possible or forthcoming, DOE will arrange for provisions that will assure long-term land ownership, stewardship, funding, and control of unauthorized activities. As noted in key documents in subsection 3.2, stewardship and control of the NTS and the Area 5 RWMS will be maintained for the foreseeable future.

2. The DOE has conducted a thorough analysis of existing and potential activities on the NTS lands, including the immediate vicinity of the Area 5 RWMS, with the goal of showing how various implemented AICs will control or prevent unauthorized activities. An update of the preliminary summary of some of those potential activities, based on Gustafson et al. [1993], is as follows:

a. Ranching. There are currently no ranching activities allowed on the NTS. These restrictions will be continued during the period AICs are in force, and ranching activities will continue to be prohibited on the NTS and the Area 5 RWMS. Though the potential exists for such use, there are currently no incentives for actual development of ranching activities. Any future grazing activities would be strictly controlled and limited by the BLM through grazing leases and permits. Fencing would prevent cattle from disturbing the disposal facility areas, caps, or reclaimed areas.

b. Farming. There are currently no farming or farm-related irrigation activities allowed on the NTS or the NTTR. These restrictions will be continued during the period AICs are in force, and farming activities will continue to be prohibited on the NTS and the Area 5 RWMS. Though the potential exists for such use, there are currently no financial incentives for actual development of farming or farm irrigation activities. Any future farming activities would be restricted and controlled by signs, fencing, land use management, and other measures.

c. Hunting. Hunting is not currently allowed on the NTS nor is such activity anticipated in the future as long as DOE and BLM land-use controls remain in effect for the NTS.

d. Scientific Activities. Research activities (vegetation studies, hydrologic studies, monitoring, passive marker placement and testing, and such) are likely to continue on the NTS and on or near the Area 5 RWMS for the foreseeable future. However, once the RWMS is capped, closed, and access is restricted, any subsequent scientific activities that go beyond support for the post-closure monitoring program will be restricted and strictly controlled. Active controls will ensure that any scientific activities can proceed undisturbed without impacting the disposal systems. Specific needs for planning and protection will be identified with each new study proposed for the area.

e. Utilities and Transportation Corridors. Currently the NTS and the RWMS area are traversed and/or bordered by highways and roads, utility lines (power, telephone, etc.), and similar infrastructure. Construction and maintenance of these provisions involve significant surface-disturbing activities. Such activities are controlled by the DOE permitting and review process, and are likely to have minimal subsurface impacts or any significant impacts on the GCD wastes, which are a minimum of $21 \mathrm{~m}(70 \mathrm{ft})$ deep. Active controls will ensure that future activities related to the utility and transportation corridors are strictly controlled consistent with permits, and that locations for these facilities are selected to avoid conflicts with permanent markers.

f. Groundwater Pumping. Gustafson et al. [1993] reported that, if the aquifer was accessible, and if water is present in sufficient quantities, it could be used for irrigated farming, commercial geothermal energy development, or human consumption. As was also noted above and in the discussion in 
subsection 4.1, irrigated farming, though possible, is not likely due to poor soils and extremely arid conditions. Also, the State of Nevada strictly regulates and controls water withdrawals consistent with yield and recharge. Thus, it was concluded that irrigated farming is possible but not probable (see also the CAD, Volume 2, section 6.7).

The known low-temperature geothermal resources in the area suggest that such energy development is highly unlikely.

g. Groundwater Pumping for Human Consumption. Human consumption of water presents the greatest potential for human intrusion. The continued high population growth in the Las Vegas area will put increased pressure and demands on the development of alternative water supplies. Current alternatives include the Colorado River allocation, water conservation, mining groundwater sources, and importing from other areas of the state, including development of the deep carbonate aquifers that underly one-third of the state (note that the uppermost alluvial aquifer in Area 5 is separated from the carbonate aquifer by a confining unit composed of volcanic tuff). Due to these population pressures, the incentive is becoming sufficiently strong to explore and extract these aquifers. Development of the deep carbonate aquifers is expensive, but as other sources of water are depleted, it may become less costly than importing water or implementing conservation measures. The deep carbonate aquifer beneath the NTS (and Frenchman Flat) consolidates into the Ash Meadows Groundwater Basin. DOE will likely be able to control water use on site, thus decreasing the likelihood of direct human intrusion into the disposal facilities and GCD boreholes (see subsection 4.1). In contrast, deep groundwater off-site that is accessible to supply the Las Vegas area cannot be so controlled. However, the results of the PA suggest that contamination of the aquifers underlying the Area 5 RWMS GCD boreholes is highly unlikely.

h. Surface Excavation for Sand and Gravel Resources. In general, information from the site indicates a very low mineral potential. There has been no historic mining activity near Frenchman Flat or any type of mining or prospecting excavations [Gustafson et al., 1993]. None of the 23 mining districts in southern Nye County report economic mineral deposits in unconsolidated alluvium.

The alluvial-fan of the Area 5 RWMS could provide a source of sufficient quantities of sand and gravel to justify excavation activities. However, because the gravels are predominantly made up of pyroclastic volcanic rocks that are friable, the quality of such gravel is not well suited for many commercial uses. Demand is another factor that is likely to preclude commercial mining of sand and gravel from the RWMS area. Demand is tied to projected infrastructure and development, which is tied to population. Gustafson et al. [1993] studied the population and demographic projections for the area and concluded that population demands around the NTS showed widely spaced, relatively small population centers in the immediate vicinity, with the largest (Las Vegas) far from the NTS. These projected populations would likely not impact the NTS area because the required resources are available nearby those centers. With a relatively low on-site population, the NTS and the Area 5 RWMS will continue to see very low demand for sand and gravel near the RWMS. Thus, these resources will not contribute greatly to the probability of IHI at the RWMS.

Even were these resources viable, the development of such would be either prohibited by AICs in force at the NTS and RWMS or limited and controlled via land use restrictions and permit requirements imposed by the DOE or the BLM. Any surface developments involving such excavation would have very low or no impact on the disposal systems. 
The primary strength

of the GCD concept over

shallow land burial

is that the wastes are so deep

that such intermediate depth burial

effectively precludes intrusion

by typical human activities.

i. Hydrocarbon Exploration. Petroleum exploration in Nevada has been limited and historical drilling information is incomplete. The only productive areas are well north of the RWMS. Thus the potential for oil and natural gas is rated low for southern Nye County. Also, very low potential exists for exploration for coal, tar sand, or oil shale. Any future exploratory drilling for minerals or hydrocarbon deposits would be prohibited by the AICs in place by DOE and the BLM.

j. Construction. Any construction in the area of the RWMS would only be allowed and permitted by DOE during the period of active institutional control. Such activity would only disturb the near surface and would not be allowed in the controlled areas that include the trenches, pits, or boreholes. Thus, controls will ensure that construction does not occur within the boundary of the RWMS and the GCD boreholes through the period of active control, and that construction will not interfere with the goals of the passive controls and markers.

k. Hostile and Illegal Activities. Example activities in this category include vandalism, sabotage, theft, and other practices. These activities are prohibited by federal and state law. Though any expected impact on the disposal system is low, these activities could affect monitoring efforts, the permanent markers, fences and signs, and other security provisions. Existing and future AICs, such as land use restrictions, access control, security patrols, and other measures will prevent or dramatically reduce the likelihood of such activities.

3. Though AICs cannot be considered effective for more than 100 years in the PA, DOE has committed to establishing and retaining these controls for as long as the DOE and the Federal Government remain viable public entities and are able to maintain ownership and control of the site. As noted earlier in this report, AICs will be maintained for the foreseeable future. However, this commitment must be tempered by the SME conclusion (noted in Table 4-2) that AICs will likely not survive "for the foreseeable future."

4. In accordance with RWMS closure plans ([BechtelNevada, 1998b] and as summarized in subsection 3.1), DOE will perform necessary maintenance operations, remedial actions, and decommissioning steps needed to establish the proper post-closure condition for the site. This will include controlling or cleaning up any releases from the site.

5. According to the NTS Routine Radiological Monitoring Plan [Bechtel Nevada, 1998a], and the provisions established for post-closure monitoring (see subsection 4.4.2 above), DOE will monitor parameters related to disposal system performance.

6. The following briefly summarizes the specific AICs to be implemented for the GCD boreholes at the Area 5 RWMS:

a. Fences and Signs. Restrictive fences and signs currently exist for the NTS and the Area 5 RWMS. DOE will upgrade the fences and signs around the RWMS following closure to clarify the hazards present and the restrictions for access and prohibited activities. Additional signs and fences may be needed for disposal system monitoring provisions in remote locations separate from the RWMS.

b. Facility Guarding, Roadways, and Patrols. The NTS, as well as the NTTR, currently provide for security patrols, access control, and roadways and other facilities and administrative provisions, including funding, needed for those purposes (see subsection 
2.2). These controls and security provisions will be continued as long as DOE, the NTTR, the BLM, and the Federal Government maintain control of the NTS. Once the Area 5 RWMS is closed, periodic patrols of this area, along with strict access control provisions, will be put into place and funded. Adequate roadways for these patrols as well as fence line maintenance, if not already present, will be constructed and maintained as needed.

c. Land Use Control and Permits. DOE and BLM will jointly (where applicable) institute land use controls and permitting requirements for all of the NTS and surrounding federal lands under their jurisdiction, consistent with the requirements and provisions of the compliance assessment documented in this report, as well as plans for long-term stewardship of the site [DOE 1998a, DOE 1998b, DOE 1998c]. These controls will provide sufficient legal authority to prevent unauthorized uses of the NTS and the Area 5 RWMS. Excluded activities, as noted above, include ranching and farming, drilling for water or other exploratory drilling for resources, hunting, surface excavation and mining, and other hostile or illegal acts. Permits will strictly control future scientific investigations, construction in or near the Area 5 RWMS, and installation or maintenance of existing or future utility and transportation provisions.

d. Land Reclamation. Any land reclamation or site restoration activities in or around the Area 5 RWMS will be conducted in accordance with the site-wide closure plans and post-closure land management plan.

e. Inspection and Maintenance. Periodic inspection and maintenance will be performed as needed for all fences, signs, roadways, permanent markers, and monitoring equipment.

f. Reporting and Corrective Actions.
Administrative controls and plans will be put into place to require reporting of activities and incidents impacting the access control and security provisions of the Area 5 RWMS (in addition to current and future reporting requirements for the NTS). Guidelines will be developed for identifying and implementing corrective measures to address abnormal conditions noted during routine security patrols, surveillance and inspections.

\subsection{Passive Institutional Controls}

\subsubsection{Requirements and Discussion}

40 CFR 191.14(c) states the following:

Disposal sites shall be designated by the most permanent markers, records, and other passive institutional controls practicable to indicate the dangers of the wastes and their location.

The regulations in 40 CFR 191.14(c) call for the "most permanent" markers, records, and other PICs that are practicable. These passive controls will need to remain in place for a much greater period of time than required for the AICs. For "several hundreds of years," these controls will reduce, but not eliminate, the likelihood of IHI. The Federal agencies involved (DOE and BLM) will retain ownership and control of the land (and land uses) the GCD boreholes are located on for as long as practicable - for the "foreseeable future". Markers and records must be durable and provide clear messages to future generations and societies regarding the risks and hazards posed by the site. The compliance assessment and application will need to provide thorough descriptions of the designs of the markers and records disposition, estimates of the periods of time such controls will endure and be understood, and justification for any credit taken for such control provisions in the PA. 


\section{Key Concepts for Passive Controls}

$\mathrm{T}$ permanent markers will delineate the facility and clearly identify hazards

$\mathrm{T}$ markers must be durable material, of low intrinsic value

$\mathrm{T}$ government land ownership and restrictions

$T$ records and archives in dispersed locales

$\mathrm{T}$ preserve knowledge about location and contents of the disposal facilities

$\mathrm{T}$ markers and records should reduce, but need not eliminate, the likelihood of IHI

$\mathrm{T}$ effectiveness for several hundred years

\subsubsection{SME Observations}

In the context of this Assurance Requirement, the SMEs separately considered two distinct forms of controls. They considered the ability to maintain site knowledge through oral or archival records, and the ability of placards and markers placed around the site to ward off potential inadvertent intruders and, hence, to deter intrusion. Site knowledge was defined by the SMEs in terms of knowledge of the exact location of the site and knowledge that the site is dangerous. The SMEs expected that site knowledge could be maintained indefinitely through formal means such as universities, libraries, localculture, oral history, and government agencies; however, access to that knowledge was expected to decline as the time lapse from major events that occurred at the NTS increases. The site knowledge resources were expected to be viable sources for many years after loss of active institutional control, provided institutional control was not lost through involuntary or abrupt means. The concern was that the existence of historical records does not imply continued reasonable access to the records. The SMEs suggested that site knowledge would be lost within a few hundred years after loss of institutional control. It was estimated that the probability that site knowledge will be lost will follow the distribution presented in Table 4-3. They based their assessments on the ability of human populations to transfer information across generations, and the relative unimportance of the LLW sites. The SMEs also accounted for current information systems technology, which they believed increase the chances of long-term maintenance of site knowledge.

\begin{tabular}{|c|c|}
\hline $\begin{array}{c}\text { Table 4-3 - Expert Elicitation Estimates of } \\
\text { Durability of Site Knowledge }\end{array}$ \\
\hline $\begin{array}{c}\text { Number of Years of } \\
\text { Site Knowledge }\end{array}$ & $\begin{array}{c}\text { Probability That } \\
\text { Site Knowledge } \\
\text { Will Be Lost }\end{array}$ \\
\hline \hline 50 & 0.25 \\
\hline 100 & 0.50 \\
\hline 140 & 0.75 \\
\hline 500 & 0.95 \\
\hline
\end{tabular}

The SMEs also evaluated the potential for placards and markers to effectively reduce the chance of future inadvertent human intrusion into the subsurface disposal units. The discussion was predicated on loss of institutional control, so that placards and markers would not be continually maintained. The primary factors identified by the SMEs for the potential effectiveness of placards and markers were their durability and interpretability over time. The SMEs were uncertain about the ability for placards and markers to endure for 10,000 years, citing the potential for weathering or erosion, and vandalism, such as theft, or forms of defacing. They discussed the types of markers that might persist for such long time frames, and suggested that objects such as large granite boulders that are engraved with the intended marks would have the least chance of being subjected to vandalism or other forms of destruction or removal. The main focus of the SMEs input, however, was on the marks or signs that might provide effective messages. They recognized that, for example, petroglyph meanings have been hotly debated for years. The SMEs considered, for example, the signs posed in "At Work in the Fields of the Bomb" [Tredici, 1987] to be far too complex, and probably not able to withstand deciphering by most people now, let alone in the future. The SMEs' focus was on deterring potential inadvertent human intruders, 
who they considered unlikely to have the expertise required to decipher unusual signs or language. Consequently, they suggested that the only type of sign that could be expected to endure and be an effective deterrent for IHI would be a simple symbolic representation of life and death (see Black et al., 2000, Appendix D). Even in this case, the SMEs recognized that some cultures use different life and death symbology now. Based on the SMEs' discussion, they assessed the probability for placards and markers to effectively deter IHI to be less than $50 \%$, probably decreasing over time.

In their discussion, the SMEs distinguished between inadvertent and "advertent" (or purposeful) intruders. Although the SMEs were informed that, from a regulatory perspective, purposeful intrusion is not regulated, they often differentiated these two intrusion scenarios. For example, where placards and markers are concerned, they recognized that intrusion might occur because of human curiosity once the placards and markers are re-discovered in the future. They cited many examples of current society uncovering artifacts and other remnants of past civilizations. They also noted that this type of purposeful investigation into the site in the distant future after loss of institutional control and site knowledge, might lead to regaining site knowledge and, possibly, institutional control if the hazards are, at that time, deemed worthy of re-instigating protection programs.

\subsubsection{DOE Actions}

The time horizons for active operation of the Area 5 RWMS, LLW facilities, and other DOE/DP operations until at least FY 2070 will delay the need for actual implementation and placement of PIC provisions applicable to the GCD boreholes. As such, over time DOE will develop a plan to design and implement the PICs that are appropriate, practicable, and effective for long-term passive control of the Area 5 RWMS and GCD boreholes. The PIC program will include, in general, the following provisions:

1. As noted in subsection 4.5.3 above, DOE has entered into agreements with the NTTR,
BLM, Fish \& Wildlife, and the State of Nevada regarding long-term ownership and control of the lands including and surrounding the NTS. Where agreements with these agencies are not possible or forthcoming, DOE will arrange for provisions that will assure long-term land ownership, stewardship, funding, and prevention of unauthorized activities.

2. DOE will design, fabricate, and install appropriate markers and monuments to demark 1) the controlled area, 2) the Area 5 RWMS, and 3) the GCD boreholes and the footprint of the disposal cells (Figure 4-1). All markers and monuments will be fabricated from durable materials of low intrinsic value (such as granite or fired clay). Markers will be randomly spaced in location and depth to dissuade organized efforts at exploration and marker collection. The messages on these markers will be simple to understand and interpret and may be provided in multiple languages.

3. DOE will identify and develop sets of records that provide a comprehensive and lasting societal memory and record of the facility. Records will define the location, design, content, and hazards of the GCD boreholes. DOE will define the distribution requirements for the record sets to include local, state, and national record centers and archives. DOE will assure financial provisions are in place for long-term control, storage, and maintenance of the record sets.

DOE intends that markers and records for the Area 5 waste disposal facilities will endure and remain as effective deterrents to human intrusion up to and beyond the period of time the Federal Government owns and maintains control of the NTS, the Area 5 RWMS, and surrounding lands. However, no credit was taken in the PA for the design or effective implementation of PIC provisions. 


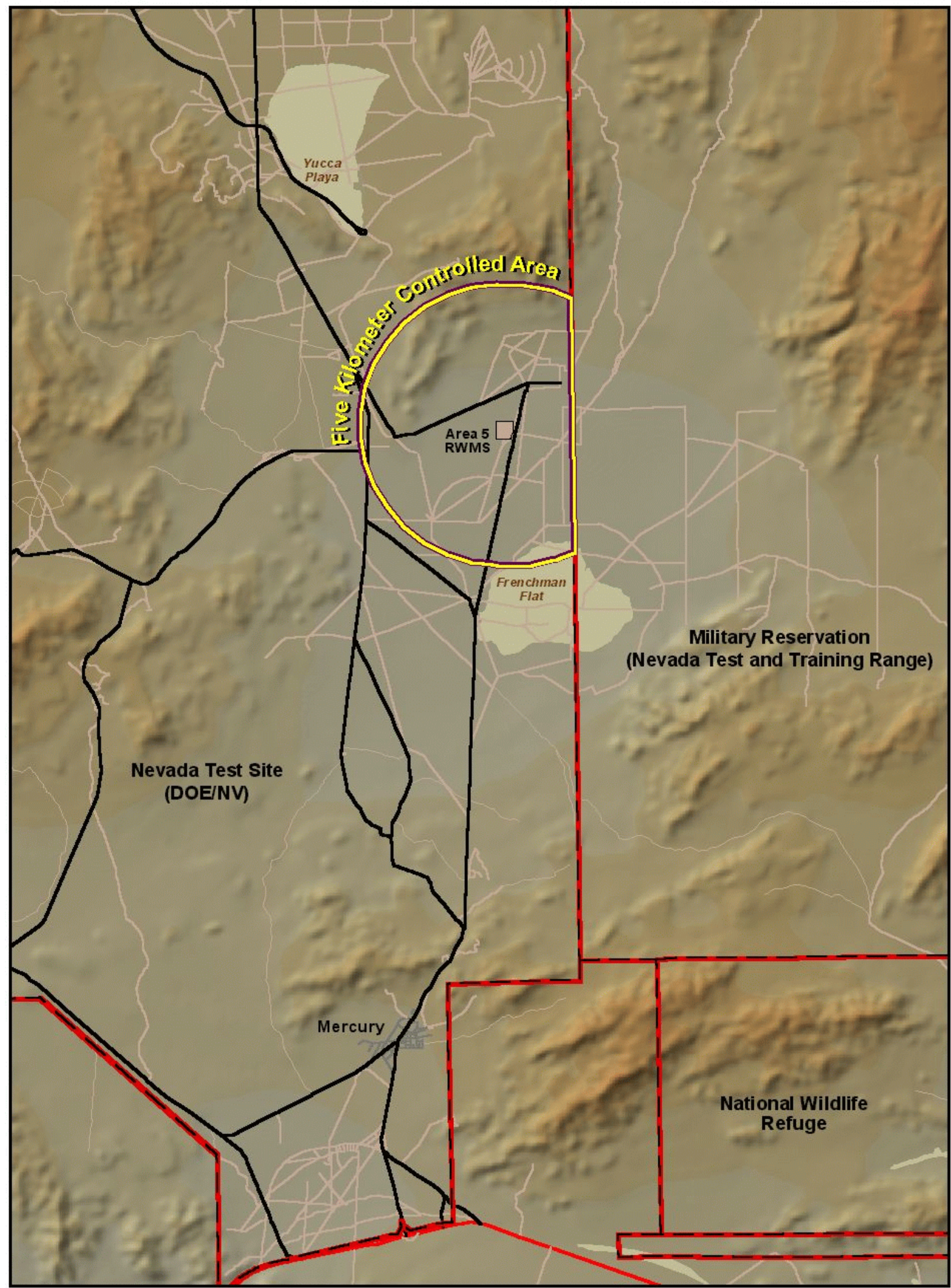

Figure 4-1. Controlled Area Around GCD Boreholes in the Area 5 RWMS 
Bechtel Nevada, 2000. Integrated Closure and Monitoring Plan for the Area 3 and Area 5 Radioactive Waste Management Sites at the Nevada Test Site, DOE/NV/11718-449, submitted to U.S. DOE, Nevada Operations Office, Las Vegas, Nevada, October 2000.

Bechtel Nevada, 1998a. Nevada Test Site Routine Radiological Environmental Monitoring Plan, DOE/NV/11718-244, submitted to US DOE, Nevada Operations Office, Las Vegas, Nevada, July 1998.

Bechtel Nevada, 1998b. Closure Program for the Area 3 and Area 5 Radioactive Waste Management Sites at the Nevada Test Site, Program Management Plan submitted to US DOE, Nevada Operations Office, Las Vegas, Nevada, September 1998.

Black, P., K. Black, M. Hooten, L. Mathai, D. Neptune, 2000. Assessing the Probability of Inadvertent Human Intrusion at Nevada Test Site Radioactive Waste Management Sites, Draft Final Report for DOE, Neptune and Company, Inc., March, 2000.

Chu, M.S.Y., E.A. Bernard, 1991. Waste Inventory and Source Term Model for the Greater Confinement Disposal Site at the Nevada Test Site, SAND91-0170, Sandia National Laboratories, Albuquerque, NM.

DOE, 1988. “Radioactive Waste Management,” DOE Order 5820.2A, September 26, 1988.

DOE, 1996a. Final Environmental Impact Statement for the Nevada Test Site and Off-Site Locations in the State of Nevada, DOE/EIS 0243, U.S. Department of Energy, Nevada Operations Office, Las Vegas, Nevada, August 1996.

DOE, 1996b. Compliance Certification Application for the Waste Isolation Pilot Plant, Submitted by U.S. Department of Energy to the U.S. Environmental Protection Agency, October 29, 1996.

DOE, 1998a. Accelerating Cleanup: Paths to Closure, DOE/EM-0362, U.S. Department of Energy, Office of Environmental Management, June 1998.

DOE, 1998b. Accelerating Cleanup: Paths to Closure, Nevada Operations Office, U.S. Department of Energy, Nevada Operations Office, Las Vegas, Nevada, June 1998.

DOE, 1998c. Nevada Test Site Resource Management Plan, DOE/NV-518,U.S. Department of Energy, Nevada Operations Office, Las Vegas, Nevada, December 1998.

DOE, 1999a. DOE Order, Manual, and Guide, 435.1-1, "Radioactive Waste Management," U.S. Department of Energy, July 9, 1999.

DOE, 1999b. From Cleanup to Stewardship, a Companion Report to Accelerating Cleanup: Paths to Closure, DOE/EM-0466, October 1999. Available at http://www.em.doe.gov/lts (Date of access: July $18,2000)$.

DOE/NV, 2001. Plan for Retrieval of Radioactive "Classified Waste" Packages from Trenches and Greater Confinement Disposal Boreholes at the Nevada Test Site Area 5 Radioactive Waste Management Site, supercedes "Transuranic (TRU) Waste Retrieval from Classified Trench T04C," dated May 7, 1992, prepared by DOE Nevada Waste Management Division, April 2001. 
EPA, 1985. "40 CFR Part 191: Environmental Standards for the Management and Disposal of Spent Nuclear Fuel, High-Level, and Transuranic Radioactive Wastes; Final Rule," Federal Register, Thursday, September 19, 1985.

EPA, 1996. 40 CFR Part 194, Part VI: Criteria for the Certification and Re-Certification of the Waste Isolation Pilot Plant's Compliance With the 40 CFR Part 191 Disposal Regulations; Final Rule, U.S. Environmental Protection Agency, Federal Register, February 9, 1996.

EPA, 1998. 40 CFR Part 194, Part III: Criteria for the Certification and Re-Certification of the Waste Isolation Pilot Plant's Compliance With the Disposal Regulations: Certification Decision; Final Rule, U.S. Environmental Protection Agency, Federal Register, May 18, 1998.

Gustafson, D.L., S.E. Rawlinson, and J.J. Miller, Summary of Natural Resources that Potentially Influence Human Intrusion at the Area 5 Radioactive Waste Management Site DOE/Nevada Test Site, Nye County, Nevada, Raytheon Services Nevada, Las Vegas, NV, August, 1993.

Price, L.L., S.H. Conrad, D.A. Zimmerman, N.E. Olague, K.C. Gaither, W.B. Cox, J.T. McCord, C.P. Harlan, 1993. Preliminary Performance Assessment of the Greater Confinement Disposal Facility at the Nevada Test Site - Volume 1: Executive Summary, SAND91-0047, Sandia National Laboratories, Albuquerque, NM

Price, L.L., 1994a. Disposal Configuration Options for Future Uses of Greater Confinement Disposal at the Nevada Test Site, SAND94-2105, Sandia National Laboratories, Albuquerque, NM.

Price, L.L., F.A. Duran, 1994b. Characteristics of Special-Case Wastes Potentially Destined for Disposal at the Nevada Test Site, SAND94-2106, Sandia National Laboratories, Albuquerque, NM.

Tredici, Robert del, 1987. "At Work in the Fields of the Bomb”, Harper and Row. 


\section{Appendix A - Assurance Provisions for the Waste Isolation Pilot Plant}

As noted in Section 1.0, discussing application of Assurance Requirements to the Waste Isolation Pilot Plant (WIPP) is valuable for two primary reasons: the GCD boreholes are subject to the identical set of Assurance Requirements; and application to WIPP provides opportunity to understand EPA's interpretation of the Assurance Requirements.

\section{A.1 Site and Project Description}

The DOE is responsible for the disposition of TRU waste generated through defense activities. The Waste Isolation Pilot Plant, located in southeastern New Mexico about $42 \mathrm{~km}$ (26 mi) east of Carlsbad, New Mexico, has been sited and constructed to meet the criteria established for the disposal of TRU waste. The WIPP is a full-scale pilot plant for demonstrating the safe management, storage, and disposal of defense-generated TRU waste. The WIPP is in the Delaware Basin in an area of gently rolling hills known as Los Medanos. Over time, the thick salt beds of the Salado Formation, which hosts the WIPP, and the Castile Formation, an evaporite deposit that underlies the Salado, accumulated in the Delaware Basin. The quality of the well water in the area has always been poor, and water for people and most livestock is supplied by pipeline. Some of the surrounding area is used by local ranchers for cattle grazing. Potash, oil, and natural gas are the primary mineral resources in the area; however, resource extraction is not allowed within the WIPP Land Withdrawal Boundaries. The Castile Formation contains pressurized brine that could affect repository performance if breached by an exploratory borehole. The Salado Formation has minimal groundwater movement; however, several rock units above the Salado could provide pathways for radionuclide migration.

The WIPP repository is located 655 meters (2150 $\mathrm{ft}$ ) below the land surface in a bed of salt that is 609 meters (2000 ft.) thick. Groundwater movement in the salt is extremely limited, but slow seepage of brine does occur. The WIPP is composed of four main shafts connected to a single underground disposal level. There are eight panels (groups) of seven rooms each for waste disposal. As each panel is filled with waste, the next panel will be mined. Before the repository is closed permanently, each panel will be backfilled and sealed, waste will be placed in the horizontal passageways between the panels and backfilled, and access ways will be sealed from the shafts. Drums and boxes containing wastes will be stacked three high in the storage rooms.

The performance criteria and other requirements that the WIPP site must meet were originally specified by the EPA in the 1985 version of 40 CFR 191 (the regulation that pertains to the GCD boreholes at the NTS). In 1987, the First Circuit court vacated and remanded the entire rule due to "arbitrary and capricious" language found in the 1985 version. In 1992, the U.S. Congress passed the WIPP Land Withdrawal Act (LWA) which, among other things, reinstated the disposal standards issued in 1985 except the groundwater protection and individual protection requirements, and mandated that the EPA (not DOE) certify the DOE's compliance with 40 CFR 191, Subparts B and $\mathrm{C}$. The LWA gave EPA the authority for issuing final radioactive waste disposal standards for HLW and TRU facilities not characterized under Section 113(a) of the Nuclear Waste Policy Act. The final standards for disposal of HLW and TRU wastes were promulgated in the December 1993 version of 40 CFR 191 and contained new Individual Protection and Groundwater Protection Requirements (the Assurance and Containment Requirements were unchanged).

EPA had the responsibility to issue the criteria that it intended to use for certification of WIPP, written as Part VI of 40 CFR Part 194 [EPA, 1996], supplemented with guidance in EPA's Compliance Application Guidance. In response, the DOE submitted the Compliance Certification Application (CCA) to the EPA on October 29, 1996 [DOE, 1996b]. This application was an extensive effort by DOE to show that the WIPP can exceed the performance required in the applicable federal regulations. Finally, on May 18, 1998, the EPA provided and documented their certification decision for WIPP as Part III of 40 CFR Part 194 [EPA, 1998]. With certification, WIPP is operational and currently receiving waste from other DOE sites. 


\section{A.2 Summary of WIPP Assurance Requirements}

The WIPP CCA is a massive work in many volumes and detailed appendices. The Assurance Requirements are summarized in Chapter 7 of that document, with details on implementation of each of the six requirements relegated to a number of appendices. What follows is based on the information provided in Chapter 7. The entire text of the CCA is available on the World Wide Web at $\mathrm{the}$ following add re s s : http://www.wipp.carlsbad.nm.us/library/cca/cca.

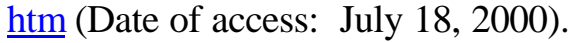

Each of the following six subsections summarizes the intended implementation of the Assurance Requirements for the WIPP site. Each subsection includes three discussions: 1) a summary of what EPA expected to see, based on 40 CFR 194 and the CCA; 2) a summary of what DOE proposed to do based on those requirements and the analysis of site-specific factors; and finally, 3) a summary of what EPA accepted or rejected in their final certification decision.

\section{A.2.1 Site Selection and Resources}

\section{A.2.1.1 What EPA Expected}

The EPA promulgated this section of the rule to discourage locating repositories in areas that contain valuable or scarce resources. The intent was to give preference to those sites that would not be as subject to exploratory activities. In assessing compliance with this requirement, EPA stated (40 CFR 194.45) that:

If performance assessments predict that the disposal system meets the containment requirements of $\S 191.13$ of this chapter, then the agency will assume that the requirements of this section and $\S 191.14(\mathrm{e})$ of this chapter have been fulfilled.

The EPA felt that the PA is the appropriate tool to weigh the advantages and disadvantages of the site with respect to potential human intrusion. EPA desired that DOE adequately account for the effects of mining and drilling activities in the performance assessment conceptual models.

\section{A.2.1.2 What DOE Committed To}

DOE took the position that, though the WIPP site was selected before promulgation of 40 CFR Parts 191 and 194, resource considerations were included in the site selection process, and the rationale for the decision was documented (in the WIPP Final Environmental Impact Statement) and supported. The types and amounts of potential resources and resource conflicts were considered in detail during the multi-step selection process. DOE concluded that the favorable characteristics of the WIPP site uniquely qualified it for a defense waste repository, and that those characteristics compensated for any increased likelihood of future disturbance.

\section{A.2.1.3 What EPA Accepted}

EPA accepted the DOE position for this Assurance Requirement because the PA incorporated human intrusion scenarios and met EPA's release limits, thus taking adequate account of favorable site characteristics versus the impacts due to the presence of valuable resources.

\section{A.2.2 Future Waste Removal}

\section{A.2.2.1 What EPA Expected}

EPA required that "any compliance application shall include documentation which demonstrates that removal of waste is feasible for a reasonable period of time after disposal." This documentation should "include an analysis of the technological feasibility of mining the sealed disposal system, given technology levels at the time a compliance application is prepared." EPA also desired that a repository meet this requirement in its design without need of additional procedures or design features. The rationale for this Assurance Requirement is to allow future generations the option of recovering wastes should they decide to do so. According to EPA, recovery need not be easy or expensive but only possible. 


\section{A.2.2.2 What DOE Committed To}

DOE asserted that removal of the waste is possible at any time after emplacement with similar mining technologies used to initially mine the repository. This operation can also be done remotely where needed. DOE provided a five-phase plan for removal of waste based on standard industry practices and procedures.

\section{A.2.2.3 What EPA Accepted}

The EPA accepted the approach and position of DOE for this Assurance Requirement. EPA agreed that the technology for removal was substantially the same as that used for disposal, and would remain available for at least 100 years after the repository is sealed. DOE acceptably identified the limitations, expense, and hazards involved in this type of operation. EPA felt that DOE "demonstrated that it is possible to remove waste from the repository for a reasonable period of time after disposal," thus demonstrating compliance.

\section{A.2.3 Barriers}

\section{A.2.3.1 What EPA Expected}

The multiple barrier concept - both natural and engineered - was established by EPA to minimize the impacts due to unexpectedly poor performance and failure of any single barrier type. This mandate came from Congress in the LWA (the multiple barrier concept predates the LWA, however). Barriers may include variations in waste form and waste packaging, engineered features of the waste disposal cell and facility housing the waste, as well as engineered and natural features of the geosphere surrounding the waste facility. EPA expected a cost and benefit study included in the compliance application to justify the selection and rejection of barriers evaluated.

It is useful to repeat here the criteria EPA established in 40 CFR 194.44 for consideration in the cost/benefit study for WIPP:

i. The ability of the engineered barrier to prevent or substantially delay the movement of water or waste toward the accessible environment;

ii. The impact on worker exposure to radiation both during and after incorporation of engineered barriers;

iii. The increased ease or difficulty of removing the waste from the disposal system;

iv. The increased or reduced risk of transporting the waste to the disposal system;

v. The increased or reduced uncertainty in compliance assessment;

vi. Public comments requesting specific engineered barriers;

vii. The increased or reduced total system costs;

viii. The impact, if any, on other waste disposal programs from the incorporation of engineered barriers (for example, the extent to which the incorporation of engineered barriers affects the volume of waste);

ix. The effects on mitigating the consequences of human intrusion.

EPA made it clear in 40 CFR 194 that it does not require specific engineered barriers or the implementation of more than one engineered barrier.

\section{A.2.3.2 What DOE Committed To}

The WIPP facility includes the concept of multiple barriers for isolation and containment of wastes. The design includes natural barriers (for example, hydrological, geological, and geochemical conditions), and engineered barriers (for example, borehole plugs, shaft seals, panel closures, and backfill). Barrier effectiveness is modeled in the PA to demonstrate the ability of the complete disposal system to meet the EPA Standards. DOE conducted extensive feasibility and cost/benefit analyses of alternative approaches to barrier design and implementation to assess the costs, benefits, and detriments of the possible approaches. After a screening process, 18 engineered alternatives met the EPA criteria. DOE specifically evaluated the advantages of a backfill that chemically altered the $\mathrm{pH}$ of brine in the disposal rooms to reduce the quantity of mobile actinides. From the analysis, DOE selected magnesium oxide $(\mathrm{MgO})$ as the backfill material that provided the desired long-term benefit. The DOE proposed to emplace a 
large amount of $\mathrm{MgO}$ around the waste drums to delay the movement of radionuclides toward the accessible environment. This backfill design, along with shaft seals, panel closures, and borehole plugs, were incorporated into the WIPP PA calculation and into the repository design.

\section{A.2.3.3 What EPA Accepted}

EPA accepted DOE's analyses and evaluations of the barrier alternatives, and the implementation of those engineered and natural barrier features selected. Public comments suggested DOE had not kept the "containment" and "assurance" requirements separate. EPA responded that engineered barriers may be used to meet the Containment Requirements, but must be used to meet the Assurance Requirements. Also, the effects of all engineered barriers must be included in the modeling conducted in the performance assessment (per $§ 191.12(a)$ ). It was shown that WIPP could comply with the Containment Requirements with or without the use of $\mathrm{MgO}$ as an engineered barrier.

\section{A.2.4 Monitoring}

\section{A.2.4.1 What EPA Expected}

In the regulations, a number of important concepts and expectations for monitoring are apparent; namely, that a monitoring plan 1) address significant disposal system parameters, 2) address important disposal system concerns, 3) obtain meaningful data in a short period of time, 4) preserve system integrity, and 5) be consistent and complementary with other monitoring programs, such as RCRA. Monitoring is an important activity to be implemented during the active institutional control period. For WIPP, EPA required DOE to conduct an analysis of the effects of certain disposal system parameters on containment. EPA specified plans for both pre-closure and postclosure monitoring. Another point made by EPA is that monitoring must not become a reason to relax the degree of care with which compliance determination is made.

\section{A.2.4.2 What DOE Committed To}

DOE developed a Pre-Closure and Post-Closure Monitoring Plan that includes 1) a confirmatory volatile organic compound (VOC) monitoring program to demonstrate the reasonableness of predictions for VOC releases; 2) a groundwater monitoring program to verify knowledge regarding groundwater flow; and 3) a geomechanical monitoring program to support decisions regarding the underground openings. DOE concluded that these programs would satisfy the requirements for RCRA monitoring. The DOE program for WIPP will also include continued observation and trending of drilling activities in the area, and subsidence monitoring. DOE considers the time for monitoring to be about 150 years, including the 50-year preclosure period and the 100-year period of active institutional controls. However, they will continue monitoring for as along as needed if meaningful data are collected or expected. To preserve the integrity of the disposal system, DOE analyzed parameters and monitoring systems from the standpoint of direct measurement during operation, use of telemetry, or use of remote sensing techniques. DOE concluded that the latter two methods were probably not useful for this monitoring program.

DOE conducted a thorough parameter effects analysis to analyze the significance of various parameters to performance assessment and, therefore, whether or not those parameters would be part of the monitoring program. EPA defined a significant parameter “...if it affects the system's ability to contain waste or the ability to verify predictions about the future performance of the disposal system." Based on this definition and the complexity of the WIPP site, the screening and analysis of parameters was extensive.

\section{A.2.4.3 What EPA Accepted}

EPA accepted the entire monitoring program proposed by DOE. Some commenters suggested additional parameters, monitoring techniques, and extended monitoring times. However, EPA concluded that this additional monitoring would provide no significant benefit because the parameters were not significant to containment or 
to verifying predictions made about the repository. All of DOE's monitoring efforts will be subject to EPA inspections.

\section{A.2.5 Active Institutional Controls}

\section{A.2.5.1 What EPA Expected}

Active control programs should be implemented for as long as such controls are useful and practical, but credit for active institutional controls (AICs) cannot be considered in the PA beyond 100 years from final closure of the repository. EPA specified that the application "shall include detailed descriptions of proposed active institutional controls, the controls' location, and the period of time the controls are proposed to remain active." The description must support any assumptions regarding the effectiveness of AICs in preventing or reducing IHI and radionuclide releases.

\section{A.2.5.2 What DOE Committed To}

AICs to be used by the DOE include facility guarding, fences, roadways, and signs, evaluation of land use in the area, land use control and permits by DOE or BLM, post-operational monitoring, land reclamation, inspection and maintenance of fences and buildings, and reporting and corrective measures. The main goal is to prevent unauthorized use of the WIPP site. The DOE approach toward defining and designing AIC was to 1) eliminate site features that would cause future generations to develop the WIPP site, 2) identify allowed and unallowed activities, 3) identify and minimize the impacts on intentional users, and 4) control allowed activities and prevent unallowed activities. DOE recognized that the programs for AICs, the monitoring program, and the decommissioning plan (for site restoration) have overlapping objectives; thus, they will be conducted simultaneously. DOE analyzed a number of existing and potential activities and the goal of active controls in controlling or preventing those activities. Activities included ranching, farming, hunting, scientific activities, utilities and transportation corridors, groundwater pumping, surface excavation, potash exploration, hydrocarbon exploration, construction, and hostile and illegal activities. The analysis included a table to show how the various AICs would control or prevent any unauthorized activities. The analysis of activities led to the design and description of the program for AICs. Finally, DOE assumed that the AIC program will be 100 percent effective against intrusion for the 100-year period following closure. DOE is committed to retaining active control over the site for as long as practicable, but at least for 100 years.

\section{A.2.5.3 What EPA Accepted}

EPA agreed with DOE's assertion that the AICs would be 100 percent effective for the 100-year period. Though complete effectiveness cannot be established with certainty, EPA agreed with the DOE analysis regarding the redundancy and overlap of the assurance programs at WIPP, and the ability of DOE as a government agency to implement and enforce these provisions. "The EPA found DOE's assumptions to be sufficient to justify DOE's assertion that AICs will completely prevent human intrusion for 100 years after closure." Therefore, DOE was found in compliance with this Assurance Requirement in the regulation.

\section{A.2.6 Passive Institutional Controls}

\section{A.2.6.1 What EPA Expected}

The markers and records used for passive institutional controls (PICs) must convey clear messages regarding location, facility design, content of the facility, and the hazards. The intent is to deter unintentional intrusions into a disposal system by people who otherwise might not be aware of the presence of radionuclides and the hazards posed by the site. EPA defined what passive controls mean toward protecting the disposal system for as long as practicable. Note that these controls include government ownership of the land and restrictions on land use at the site. EPA provided guidance on what subjects to address and document in order to demonstrate compliance with this Assurance Requirement. Those subject areas included 1) detailed descriptions of the controls (markers, records, etc.), 2) an estimate of the period of time the passive 
institutionalcontrols are expected to endure and be understood, and 3) justification for any credit taken in the PA for the period of time the passive institutional controls reduce the likelihood of IHI. EPA suggested that the credit must be based on proposed effectiveness over time, and would take the form of reduced likelihood of IHI (in the PA) over "several hundred years." DOE was prohibited from assuming that PICs could entirely eliminate the likelihood of IHI into WIPP.

\section{A.2.6.2 What DOE Committed To}

DOE's design for PICs includes redundant markers, highly durable materials with low intrinsic value, messages in multiple languages, and record storage in multiple locations. Over a period of years, DOE convened panels of experts (the "Futures Panel" and the "Markers Panel") to identify what future societies might be like, and to determine the kinds of messages and markers that would most likely endure and remain understood in those future states. From these assessments, DOE developed a set of PICs to include 1) boundary monuments for the withdrawal area; 2) markers at the footprint of the repository to delineate the outer boundary of the subsurface facility, a berm (including an engineered magnetic signature) surrounding the footprint, a surface information center at the center of the footprint, a buried room halfway between the information center and the berm, a buried room halfway between the berm and the hot cell, and randomly-spaced buried markers across the footprint; 3 ) records distributed to national and international archives; 4) records submitted to record centers locally, nationally, and internationally; 5) government control and land use restrictions; and 6) other means of communication in references, books, maps, and atlases.

By random and redundant placement, use of durable materials and installation procedures, and multiple languages, DOE suggests these markers will likely be found by any intruder and be understood and endure for thousands of years. Submittal of records to over 100 archives and records centers world-wide will ensure a lasting societal memory and record of the facility. DOE intends to specify a 10,000-year record retention period which will obviously entail very long-term financial obligations and commitments. DOE intends to establish a testing program prior to implementation to assess the effectiveness of the messages and the media. Finally, DOE prepared a long-term schedule for the implementation of the PICs.

DOE contends that the range and type of messages, varying in complexity and language, will help ensure long-term endurability, perhaps "for many hundreds to thousands of years." DOE analyzed the markers design and placement against historical analogues and contends they have "the capability of lasting in excess of several thousand years." The Markers Panel proposed that messages would have a high probability (greater than 0.70 ) of being understood by all potential levels of technology for at least 2,000 years. DOE concluded that identical messages in the records archives would also be interpretable for as long as those documents survived.

With respect to the credit taken for PICs in reducing the likelihood of IHI, DOE made reference to an EPA statement in the Preamble to 40 CFR 194 that says:

Having considered the public comments regarding PICs, the Agency believes that such credit could be no more than approximately 700 years past the time of disposal.

However, later in that same Preamble section after an extensive discussion regarding the durability of PICs and the acceptable credit DOE might take, EPA took the following final stance for the Rule:

Based on the public comments and consistent with EPA's general view that it is inappropriate to rely on PICs for very long periods of time, EPA is constraining in the final rule the length of time that EPA could consider granting credit for PICs to several hundred years.

Based on the former statement, DOE chose to consider the 100-year credit for active institutional controls, followed by credit for PICs from year 100 to year 700. Based on the studies regarding the 
longevity of PICs, DOE felt that failure of the PICs over the entire withdrawal area will not likely occur in the time frame of interest for the PA. They analyzed the durability of marker and record messages, the English language, and the potential for human error in planning, setting up, and actually drilling in the vicinity of the repository. From this, DOE concluded that there is a 0.01 bounding value for the failure rate of drilling. DOE then concluded that PICs are considered to be 0.99 effective in deterring IHI over the entire withdrawal area for the 700-year period of time suggested in the Preamble to the rule.

\section{A.2.6.3 What EPA Accepted}

EPA proposed that DOE met the requirements for providing the detailed descriptions of the PICs and estimating the time they would remain durable and understood. EPA provided conditional acceptance in requiring that DOE provide more information on the fabrication and completion schedule for the markers, and acceptance of WIPP records by various proposed recipients. EPA proposed to deny DOE's assertion that PICs would remain 99 percent effective in preventing IHI for the first 700 years after closure. EPA felt an expert judgement elicitation was needed to support this claim for credit. EPA felt the uncertainties were too great in this area of resource exploitation to support near 100 percent effectiveness. In the response to the CCA, EPA made it clear that the decision "applies only to the credit proposal in the CCA and should not be interpreted as a judgement on the use of PICs credit in performance assessments generally." 
This page intentionally left blank. 


\begin{tabular}{|c|c|}
\hline Review Team Issue & Response \\
\hline $\begin{array}{l}\text { Lack of system planning and design to } \\
\text { demonstrate compliance with Assurance Rqmts }\end{array}$ & $\begin{array}{l}\text { DOE/NV agrees that the assurance requirements } \\
\text { are a critical part of the requirements of } 40 \text { CFR } \\
191 \text { and intends to meet those requirements. The } \\
\text { GCD boreholes are part of the much larger Area } \\
5 \text { RWMS, requiring integrated planning and } \\
\text { closure with that facility. As such, plans } \\
\text { subsequent to the GCD PA will provide details } \\
\text { relative to closure, monitoring and long-term } \\
\text { stewardship, consistent with } 40 \text { CFR 191, DOE } \\
\text { Orders, and the Area } 5 \text { Disposal Authorization } \\
\text { Statement. }\end{array}$ \\
\hline $\begin{array}{l}\text { Perception that DOE/NV is not committed to } \\
\text { compliance with Assurance Requirements. }\end{array}$ & $\begin{array}{l}\text { The GCD PA report Volume } 4 \text { contends that the } \\
\text { PA methodology, which demonstrates compliance } \\
\text { and treats uncertainty throughout the process, } \\
\text { minimizes the need for "exhaustive" reliance on } \\
\text { the Assurance Requirements (see the report } \\
\text { abstract and section 1.4). The italicized statement } \\
\text { from the EPA standard at the end of section } 1.5 \\
\text { de-emphasizes "excessive reliance on long-term } \\
\text { maintenance and surveillance." However, } \\
\text { DOE/NV is committed to meeting the Assurance } \\
\text { Requirements of } 40 \text { CFR } 191 \text {. Minor } \\
\text { modifications were made to subsections } 1.4 \text { and } \\
\text { 1.5.4 to clarify this issue. }\end{array}$ \\
\hline $\begin{array}{l}\text { Lack of details regarding active institutional } \\
\text { controls (AIC) for minimum time periods. }\end{array}$ & $\begin{array}{l}\text { No changes to Volume } 4 \text { were made. The } 100 \text { - } \\
\text { year time frame for AICs is the maximum that } \\
\text { may be assumed and taken credit for in the PA; a } \\
\text { minimum requirement is not identified. There is } \\
\text { extensive discussion throughout Volume } 4 \\
\text { regarding the intent of DOE and DOE/NV to } \\
\text { maintain long-term stewardship, now and for the } \\
\text { "foreseeable future." Very specific summaries } \\
\text { and details of the AICs that are and will be } \\
\text { implemented are provided in subsections } 2.1,2.2 \text {, } \\
\text { and particularly 4.5.3. }\end{array}$ \\
\hline $\begin{array}{l}\text { Lack of GCD borehole monitoring program } \\
\text { description. }\end{array}$ & $\begin{array}{l}\text { Volume } 4 \text { now references the Bechtel Nevada } \\
2000 \text { Integrated Closure and Monitoring Plan; } \\
\text { specific references are in subsections } 3.1 .2 \text { and } \\
\text { 4.4.2. The GCD boreholes are included in the } \\
\text { integrated monitoring plan (sections } 1.2 .1,5.1-5.3 \text {, } \\
6.3 \text {, and extensive discussion of AICs in } 6.4 \text { based } \\
\text { on the GCD PA). DOE/NV is committed to } \\
\text { meeting the monitoring program aspects of the } \\
\text { Assurance Requirements through the Integrated } \\
\text { Closure and Monitoring Plan. }\end{array}$ \\
\hline
\end{tabular}




\begin{tabular}{|c|c|}
\hline Review Team Issue & Response \\
\hline $\begin{array}{l}\text { Lack of markers, records, and other Passive } \\
\text { Institutional Controls (PICs). }\end{array}$ & $\begin{array}{l}\text { No changes were made to Volume } 4 \text {. Specifics } \\
\text { for commitments that will not be needed for } \\
\text { decades are of marginal value. The GCD } \\
\text { boreholes are inactive cells within an active LLW } \\
\text { facility. Subsection } 4.6 \text { provides a general } \\
\text { discussion of compliance requirements for } \\
\text { markers and records; preliminary designs and } \\
\text { technologies for markers and records are included } \\
\text { in the Integrated Closure and Monitoring Plan. } \\
\text { Passive controls are not needed during operational } \\
\text { and active institutional control periods; such } \\
\text { controls, when needed, will be addressed in future } \\
\text { integrated site closure plans. The Sandia Records } \\
\text { Center provides supporting project records that } \\
\text { will be transferred to DOE/NV when the project } \\
\text { is closed out. }\end{array}$ \\
\hline $\begin{array}{l}\text { Engineered barrier systems were not included in } \\
\text { the analysis. }\end{array}$ & $\begin{array}{l}\text { DOE/NV intends to include engineered barriers in } \\
\text { the final assessments of the GCD boreholes prior } \\
\text { to closure of the Area } 5 \text { RWMS. Subsections } 1.6 \\
\text { and } 4.3 .3 \text { were modified accordingly. Also, } \\
\text { subsection } 4.3 .2 \text { was slightly modified to clarify } \\
\text { the distinction between "protective barriers" that } \\
\text { are not required by the EPA regulations, and } \\
\text { barriers to waste isolation. }\end{array}$ \\
\hline $\begin{array}{l}\text { Lack of discussion regarding avoiding areas with } \\
\text { exploitable resources. }\end{array}$ & $\begin{array}{l}\text { No changes were made to Volume } 4 \text {. } \\
\text { Subsections } 4.1 .3 \text { and, particularly, } 4.5 .3 \text { and } \\
\text { related cited references provide significant detail } \\
\text { supporting this aspect of the Assurance } \\
\text { Requirements. }\end{array}$ \\
\hline $\begin{array}{l}\text { Need to describe methods and schedules for } \\
\text { future waste removal. }\end{array}$ & $\begin{array}{l}\text { Detailed discussion of schedules, costs, and } \\
\text { methods for future waste removal is not } \\
\text { appropriate in this document. Volume 4, section } \\
\text { 4.2.2 establishes the technical feasibility of waste } \\
\text { removal. A report entitled "Retrieval of Waste } \\
\text { Packages from Greater Confinement Disposal } \\
\text { Borehole U5-RWMS-04C," dated March 30, } \\
1992 \text { adequately describes retrievability of wastes } \\
\text { from the GCD boreholes. This report was } \\
\text { updated in April } 2001 \text { and was referenced. }\end{array}$ \\
\hline
\end{tabular}




\section{Distribution:}

3 U.S. Department of Energy

Nevada Operations Office

Waste Management Division

Attn: Frank Di Sanza

DOE/NV/WMD

232 Energy Way

North Las Vegas, NV 89030

MS ORG Name

$1 \quad 0771 \quad 6800 \quad$ M. Chu

$1 \quad 0735 \quad 6115$ E. Webb

$3 \quad 0735 \quad 6115 \quad$ J. Cochran

$2 \quad 0731 \quad 6850 \quad$ NWMP Library

19018 8945-1 Central Technical

Files

$20899 \quad 9616 \quad$ Technical Library

$1 \quad 06129612$ Review and Approval

Desk for DOE/OSTI 